\title{
DO WE REALLY KNOW THE PREDICTORS OF COMPETENCE-CREATING R\&D SUBSIDIARIES? UNCOVERING THE MEDIATION OF DUAL NETWORK EMBEDDEDNESS
}

\section{RUNNING TITLE: DO WE REALLY KNOW THE PREDICTORS OF COMPETENCE-CREATING R\&D SUBSIDIARIES}

\begin{abstract}
Many changes have been recorded in the R\&D role played by the foreign subsidiaries of multinational corporations (MNCs), to the extent that today many are recognised as key players in the development of firm innovation-related competences. Given this trend, we examine the predictors of a subsidiary's R\&D role as a competence-creating contributor to the MNC's long-term success. Traditionally, the predictors of subsidiaries' $R \& D$ roles have been sought in the specific features of the internal corporate and external host-country environments. However, we find that favourable corporate- and country-level conditions may not necessarily lead to the enhancement of a subsidiary’s R\&D role unless dual embeddedness - that is, the subsidiary's embeddedness in the knowledge networks of the MNC (internal embeddedness) and in those of the host country (external embeddedness) - is well established. The main contribution of this paper is the development of a multiple mediation model that disentangles the way in which corporate and host-country environments interrelate with a subsidiary's dual embeddedness in the expected configuration of its competence-creating $R \& D$ role. In developing the model, we use the PLS-SEM method to estimate the relationship between these elements and, eventually, to forecast the subsidiary's competence-creating R\&D role. The proposed model should help managers shape the fate of the subsidiary's R\&D strategic role.
\end{abstract}

\section{Keywords:}

Technology strategy; R\&D; network embeddedness; multinational; subsidiary; competence-creating role. 


\section{INTRODUCTION}

Prior research has documented the increasingly important role played by the subsidiaries of multinational corporations (MNCs) in building innovation-related competences in an international basis. This development has, in turn, triggered international knowledge-seeking strategies in the quest for long-term competitiveness (Edler, 2004). Some subsidiaries are accordingly given R\&D mandates to explore local knowledge and gain access to expertise that is complementary to the firm (Santangelo, 2012), which when leveraged through the transfer of knowledge between MNC units provide a competitive advantage for the whole corporation (Birkinshaw, Hood, \& Jonsson, 1998; Foss \& Pedersen, 2004; Frost, 2001). As a result, over time, some subsidiaries become 'competence-creating' units contributing to the knowledge of other subsidiaries, while many others become the recipients of this knowledge, or 'competence-exploiting' units (Cantwell \& Mudambi, 2005). This dichotomy has emerged in parallel with the evolution of MNC structures towards network-based systems (Wang \& Suh, 2009). The notion of the internationally networked MNC, and its corollary, the geographical dispersal of sources of knowledge (Cantwell, 2009), implicitly recognises the subsidiary's potential to access and share knowledge within two distinct contexts: within the MNC itself and within the host countries in which it operates (Ghoshal \& Bartlett, 1990). Given the importance of subsidiary engagement in network linkages for upgrading their own competences and contributing to the MNC's overall capabilities, this study explores the "dual" embeddedness of competence-creating R\&D subsidiaries as a key factor for future firm-specific advantage.

Existing studies on subsidiary R\&D roles pay little attention to the impact of subsidiary involvement in corporate and local network linkages (Wang, Liu, \& $\mathrm{Li}, 2009$ ). On the one hand, traditional academic models view the MNC as a set of units operating in multiple environments and the R\&D role of each subsidiary largely as a function of the characteristics of its local environment (see, for e.g., Ghoshal \& Nohria, 1989; Jarillo \& Martínez, 1990). They tend to consider this environment as a determinant force that affects all units operating at the same location equally (Holm, Holmström, \& Sharma, 2005). On the other hand, many other studies consider subsidiary roles as being driven primarily by the internal corporate management and focus on the traditional facets of the headquarterssubsidiary dyad, such as headquarters assignment or subsidiary initiatives (e.g. Ambos, Andersson \& Birkinshaw, 2010; Birkinshaw et al., 1998; Dörenbächer \& Gammelgaard, 2006), in part, assuming that an MNC's subsidiaries have the same opportunity to benefit from the same corporate background.

Yet, earlier research has shown that subsidiaries located in the same country and subsidiaries of the same MNC operating in different countries varied markedly in their ability to fulfil international responsibilities, ranging from the undertaking of multiple competence-creating mandates to the fulfilling of none whatsoever (Moore, 2001). This suggests that environmental predictors (both 
corporate- and country-level predictors) by themselves cannot fully account for the heterogeneity of R\&D subsidiaries and that a third explanatory factor concerned with unequal access to knowledge resources in the two contexts must exist. With the aim of uncovering this predictor, this study seeks to provide fresh answers to the traditional question of: Why are some champion subsidiaries more R\&D competence-creators than others although operating in the same location or belonging to the same MNC?

It is our contention that the answer to this question can be found in the concept of network embeddedness, whereby the way in which, and the extent to which, subsidiaries are embedded in internal and external networks can vary. We believe that directly linking corporate- and country-level predictors to subsidiary $R \& D$ roles can result in misleading forecasts. This is because differences in the relational embeddedness of subsidiaries - understood as the variety of interactions and the quality of the linkages they develop in their networks (Figueiredo, 2011; Giroud \& Scott-Kennel, 2009; Santangelo, 2009) - lead to differences in their absorption, creation and sharing of knowledge and, hence, to different $R \& D$ roles. In exploring this question, we aim to provide a better understanding of the twin impacts of environmental predictors and dual (internal and external) embeddedness.

While studies examining subsidiaries from this dual-network perspective are increasingly common (see, e.g., Figueiredo, 2011; Helble \& Chong, 2004; Wang et al., 2009; Yamin \& Andersson, 2011; Ciabuschi, Holm, \& Martin, 2014; Oehmichen \& Puck, 2016, Bresciani \& Ferraris, 2016), few consider the simultaneous effect of internal and external embeddedness on subsidiary R\&D roles (with the notable exceptions of Wang et al., 2009; Andersson, Dellestrand \& Pedersen, 2014; Achcaoucaou, Miravitlles, \& León-Darder, 2014) and even fewer, if any, attempt to demonstrate how corporate- and country-level predictors might be related to dual embeddedness in determining a subsidiary's R\&D role. Indeed, the calls to 'unpack' the dual or multiple-embeddedness of subsidiaries from other organisational arrangements are constant in the literature (Cantwell, 2009; Meyer, Mudambi, \& Narula, 2011; Collinson \& Wang, 2012; Oehmichen \& Puck, 2016).

This study seeks to contribute the literature by developing a model that combines both the influence of the corporate and country environments with the effects of dual embeddedness so as to provide a better understanding of the predictors of subsidiaries' competence-creating roles. By adding concepts and insights from the network-based view to the literature on subsidiary's R\&D, our analysis is able to go further than previous studies and uncover several mediations that determine the strength of internal and external influences. Using a partial least square (PLS) approach to structural equation modelling on a sample of 111 foreign-owned subsidiaries in Spain, our results indicate that performing a competence-creating R\&D role depends not only on favourable corporate and country environments, ; 
but also on the subsidiary's simultaneous embeddedness in corporate and local networks, since they mediate the relationship between environmental predictors and R\&D roles.

The paper is organised as follows: the next section provides a brief overview of the relevant theory, while section 3 derives the hypotheses that should serve to disentangle the effects of corporate- and country-level predictors and dual embeddedness on competence-creating R\&D roles. Section 4 describes the data, methods, and variables used to run the forecasting model. The empirical findings of the multiple mediation analysis are presented in section 5 and their implications are discussed in section 6

\section{THEORETICAL FRAMEWORK}

Since scholars began to identify subsidiaries as important actors in the creation and maintenance of the MNC's firm-specific advantage (Cavanagh \& Freeman, 2012), two prominent views emerged. At the beginning of the eighties, many empirical studies, taking an industrial-organisation perspective (Porter, 1980), claimed that the differentiated roles played by subsidiaries was largely dependent on the characteristics of their local environment (Ghoshal \& Nohria, 1989; Jarillo \& Martínez, 1990). Later, towards the end of the eighties, studies grounded in the resource-based view suggested that as subsidiaries develop their level of competences, they become better equipped to fulfil more advanced roles (Cavanagh \& Freeman, 2012).

Although these two perspectives have added greatly to our understanding of the way in which subsidiaries contribute to achieving a firm's competitive advantages, they overlook the fact that a MNC constitutes a network of internationally dispersed units (Zander, 1999), each of which is embedded in local networks (Andersson, Forsgren, \& Holm, 2002; Forsgren, Holm, \& Johanson, 2005). This conceptualization of the MNC as a differentiated network gave way in the late nineties to the network-based view (Dyer \& Singh, 1998; Gulati, 1999). From this perspective, the MNC is able to share existing knowledge and to combine it to build new knowledge, by tapping into a range of sources available in its subsidiaries (Frost, 2001). As such, a subsidiary's critical resources can extend across country or firm boundaries and can emerge from idiosyncratic exchange relationships with different counterparts (Dyer \& Singh, 1998). Thus, each specific relationship may expose subsidiaries to new ideas and opportunities, providing them with unique strategic access to new knowledge and learning opportunities (Santangelo, 2009).

Consequently, each of the foregoing perspectives differ in its primary focus - be it industry/location, resources/capabilities or linkages, respectively. The central thesis of this article, however, is that focusing on just one of these areas severely limits our ability to account for a subsidiary's contribution 
to a firm's competitive advantage. Hence, what we propose and test is a comprehensive framework that integrates theoretical insights on the effect of both country- and corporate-level predictors and dual embeddedness in the shaping of subsidiary R\&D roles.

\section{HYPOTHESIS DEVELOPMENT}

\subsection{Mediating effect of the external MNC network}

Grounded in the industrial-organization perspective, environmental factors in host countries are assumed to contribute to the development of MNC subsidiary competences and, thus, to predict subsidiary R\&D roles. Birkinshaw \& Hood (1998: 775) refer to them as factors of 'local environment determinism' and Cantwell \& Mudambi (2005: 1113) allude to 'locational determinants' to show that $\mathrm{R} \& \mathrm{D}$ development is conditioned by the 'characteristics of the location in which the subsidiary is situated' in terms of quality and resource conditions. The main argument underpinning this environmental deterministic view is that, in essence, each subsidiary is affected by operating under a unique set of conditions (identified in Porter's (1990) diamond model as customers, competitors, suppliers and factor endowments) which constrains or determines a firm's competitiveness. For instance, the level of competition in the environment puts pressure on firms to be innovative and to upgrade their competences in order to outperform their competitors (Holm, Malmberg, \& Sölvell, 2003). Similarly, consumer discernment and sophistication push MNC units to develop new practices and competences to satisfy demanding customers (Beise, 2004). Specialised suppliers, too, may stimulate the development of competences in firms that agglomerate in a particular location (Shaver \& Flyer, 2000). Physical proximity clearly matters in generating agglomeration economies and knowledge spillovers among firms located in the same territory (Jaffe et al., 1993; Audretsch \& Feldman, 1996; Almeida \& Kogut, 1999; Alcacer \& Chung, 2007). Hence, as a baseline, we assume a positive relationship exists between the strengths of a country's environment (country-level predictors) and the likelihood of a subsidiary performing a competence-creating R\&D role.

Although Porter's (1990) model focuses on a 'firm's location advantage in leading-edge clusters', its four main dimensions are equally applicable when assessing the dynamism of the subsidiary's external environment (Birkinshaw \& Hood, 1998). In this sense, Frost, Birkinshaw, \& Ensign (2002) examined the influence of a host country's 'diamond strength' to predict the emergence of centres of excellence around the world, but they found no significant relationship between them. Likewise, Foss \& Pedersen (2002) used the elements of Porter's diamond model to assess the transferability of knowledge sourced from subsidiaries' local environments and found 'cluster-based knowledge' the least interchangeable among a corporation's units. Moreover, Holm et al. (2005) were unable to verify a relationship between the dimensions of a competitive environment and a subsidiary's impact on the development 
of MNC competence, except through external network relationships. All in all, these inconclusive insights reveal the need to identify a catalyst of the effects of country-level predictors on subsidiary R\&D roles. Therefore, to understand the phenomenon it is necessary to consider not only location issues at the country-level but also local network relationships as the main device for leveraging environmental factors.

Subsidiaries develop their technological competences by active participation in relationships with local agents, benefitting from agglomeration economies and localised knowledge in the host country (Jaffe et al., 1993; Audretsch \& Feldman, 1996; Alcacer \& Chung, 2007). As knowledge is partially tacit and localised, its transfer needs frequent interaction, facilitated not only by physical proximity (Almeida \& Kogut, 1999; Alcacer \& Chung, 2007) but also by embedding in long-lasting network relationships with host-country actors (including customers, suppliers, universities, science centres and the authorities) (Andersson et al., 2002). This is what is understood as external embeddedness from the network-based view. The underlying idea is that the maintenance of strong, trustful and cooperative ties with local actors can potentially establish the basis for learning, generating and transferring knowledge beyond the boundaries of the firm (Al-Tabbaa \& Ankrah, 2016), where this knowledge is, in turn, the basis for developing technological competencies to undertake innovative activities (Figueiredo, 2011). In this sense, Andersson et al. (2002) found that external technical embeddedness - the type of embeddedness associated with $R \& D$ activities - has a positive impact both on the subsidiary's expected performance and on its role in the development of products and production processes in the MNC.

Thus, the reason why some subsidiaries achieve better innovative performance than others (despite they operate in the same environment), can be explained by the breadth (diversity of agents) and depth (commitment and trust) of their linkages with local partners. It would seem that improvements in a subsidiary's R\&D role can be achieved, therefore, by promoting their effective integration in the local environment and that they cannot simply be attained by locating in a munificent location (Cantwell, 2009). In short, the effect of environmental characteristics as a source of competitiveness lies in the proximity of the subsidiary to the country's national innovation system and to a greater extent in its interaction via relational embeddedness.

While previous studies have considered the evolution in a subsidiary's R\&D role to be driven by favourable/unfavourable environment conditions (Benito, Grøgaard, \& Narula, 2003; Frost, 2001), we seek to relate location advantages to the relationships forged with actors in the external environment (see Figure 1). We argue that the degree of local embeddedness reflects how well the subsidiary takes advantage of challenging competition, demand market conditions, factor endowments, suppliers and 
related industries to contribute to the MNC's overall competences. Seen in this way, the effects of favourable local conditions are channelled through local embeddedness. Hence, we posit:

Hypothesis 1: The relationship between country-level predictors and a subsidiary's competencecreating R\&D mandate is mediated by its external local embeddedness.

Figure 1. Hypothesis 1

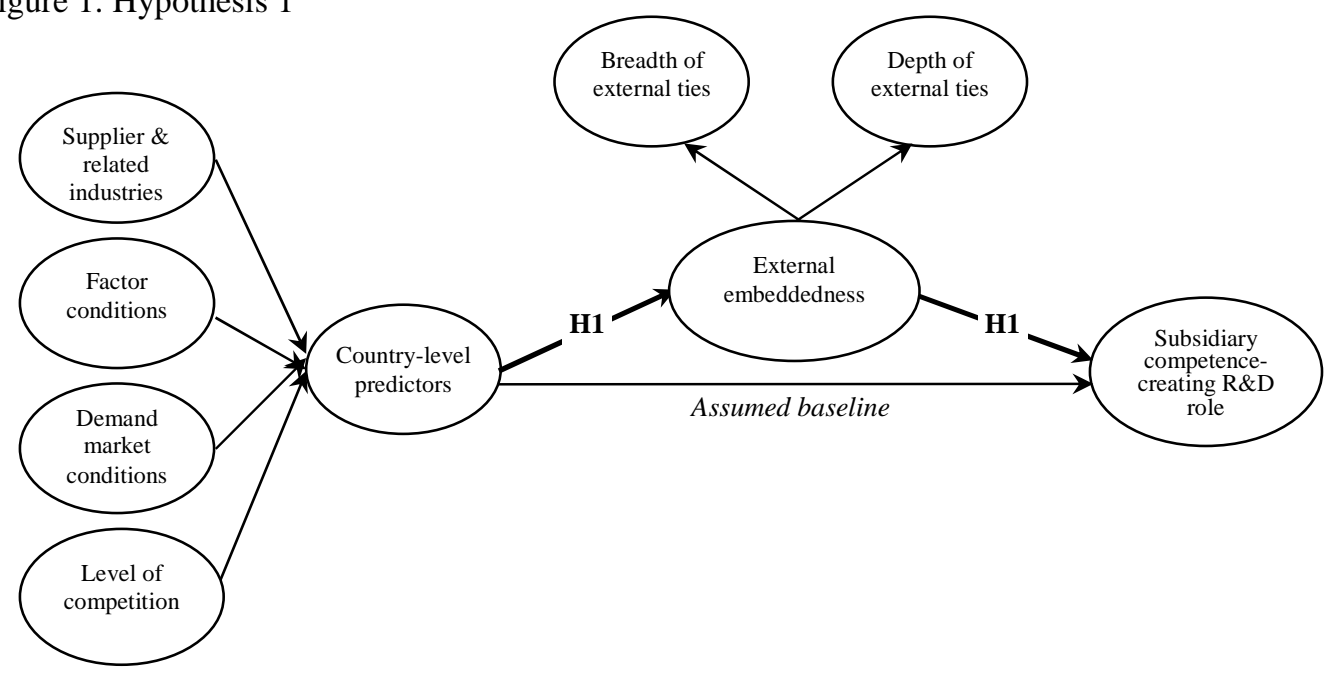

\subsection{Mediating effect of the internal MNC network}

Studies grounded in the resource-based view have demonstrated the potential of subsidiary units to achieve competence-creating roles through their entrepreneurial efforts and initiatives and, thus, to expand their value-adding activities, their markets and their responsibilities. Such actions, along with the leadership of the subsidiary managers, ensure that the resources and capabilities developed gain headquarters' recognition (e.g. Birkinshaw, 1997; Birkinshaw et al., 1998; Cantwell \& Mudambi, 2005; Cavanagh \& Freeman, 2012; Dörrenbächer \& Gammelgaard, 2006; Pearce, 1999; Roth \& Morrison, 1992; Scott, Gibbons, \& Coughlan, 2010).

Specifically, subsidiary entrepreneurship requires the subsidiary to take risks, and to be both innovative and proactive (Dimitratos, Lioka \& Young, 2014). These features explain why some subsidiaries do efforts to develop new products, improve the production processes and bid for internal corporate investments (Verbeke \& Yuan, 2013). In fact, risk-taking behaviour thrives in a true entrepreneurial culture (Barringer \& Bluedorn, 1999; Covin \& Slevin, 1989), which is shaped by either parent-induced or subsidiary-driven actions (Kuratko, Montagno, \& Hornsby, 1990). 
It has been postulated that subsidiary initiative can have a positive impact on its competence-creating role (e.g. Taggart, 1996; Birkinshaw, 1996; Birkinshaw et al., 1998; Pearce, 1999; Cantwell \& Mudambi, 2005; Young \& Tavares, 2004; Scott et al., 2010; Dimitratos, Lioka \& Young, 2014), and even in the absence of specific initiatives, a subsidiary's entrepreneurial culture may still have a positive effect on the development of distinctive capabilities. Indeed, Birkinshaw et al. (1998) considered subsidiary initiative to be a particular manifestation of an entrepreneurial atmosphere and classed them as a separate dimension.

The leadership provided by a subsidiary's top management can likewise be expected to have a direct influence on its competence-creating $\mathrm{R} \& \mathrm{D}$ role, not only by providing direction and by fostering entrepreneurial drive among the subsidiary's employees (Ghoshal \& Bartlett, 1994), but also by championing and sponsoring the assignment of new international mandates to the subsidiary (Birkinshaw, 1997; Birkinshaw et al., 1998). For example, Cantwell \& Mudambi (2005) conclude that gaining a competence-creating $R \& D$ mandate requires, among other factors, the ability of the subsidiary's managers to develop and exercise a 'voice' in the wider corporate group. Ling, Floyd, \& Baldridge (2005) support this view by stressing the effect of quality relationships between subsidiary managers and targeted top managers in 'issue selling'. Conroy and Collings (2016) go a step further by exploring the mechanisms through which issue selling may result in gaining legitimacy for subsidiary initiative. Thus, adhering to traditional theories, as a baseline, we assume a positive relationship between the strength of corporate-level predictors and the likelihood of a subsidiary performing a competence-creating $\mathrm{R} \& \mathrm{D}$ role.

However, these internal predictors of subsidiary strategic role have been expanded by the findings from network-based research. The latter highlight the interdependence of the internal corporate actors in developing competences and in creating a competitive advantage through the building of close ties of trust within the MNC, boosting the MNC's competitiveness (Álvarez, Marin, \& Fonfría, 2009). According to Schneckenberg, Truong and Mazloomi (2015) intra-firm knowledge sharing and organisational learning processes nurture microfoundational sources of innovative capabilities. Here, drawing specifically on Ambos et al.'s (2010) study, we consider internal embeddedness as being positively related to a subsidiary's strategic importance as a competence provider to the corporation, motivating headquarters involvement in the development of subsidiary innovation (Ciabuschi, Dellestrand, \& Martín Martín., 2011). From a managerial perspective, if subsidiary managers can build good relationships of trust with their counterparts in head office and in their sister affiliates, then they can strengthen internal cooperative ties, develop intra-corporate joint research, increase their visibility and draw the parent company's attention to particular issues (Bouquet \& Birkinshaw, 2008; Dutton, Ashford, O'Neill, \& Lawrence, 2001). 
Consequently, the building of a close-knit internal network is critical for the development of a subsidiary's R\&D roles, as it provides the basis for leveraging subsidiary corporate-level environment and for exploiting the knowledge and capability dependency of its sister affiliates. Even though a subsidiary displays a strong entrepreneurial culture, undertakes risky initiatives or has powerful leaders in positions of command, these factors may all fall on deaf ears if it is not well connected with the rest of the MNC's units (Birkinshaw \& Ridderstråle, 1999), as these internal network linkages are the channels via which subsidiary knowledge is made available to the rest of the MNC (Adenfelt \& Lagerström, 2006). Moreover, the network ties influence the strategic context for decision making in an MNC (Garcia-Pont, Canales, \& Noboa, 2009) and, thus, they affect decisions regarding which subsidiaries should be allocated R\&D mandates. Hence:

Hypothesis 2: The relationship between corporate-level predictors and a subsidiary's competencecreating $R \& D$ mandate is mediated by its internal corporate embeddedness.

Figure 2. Hypothesis 2

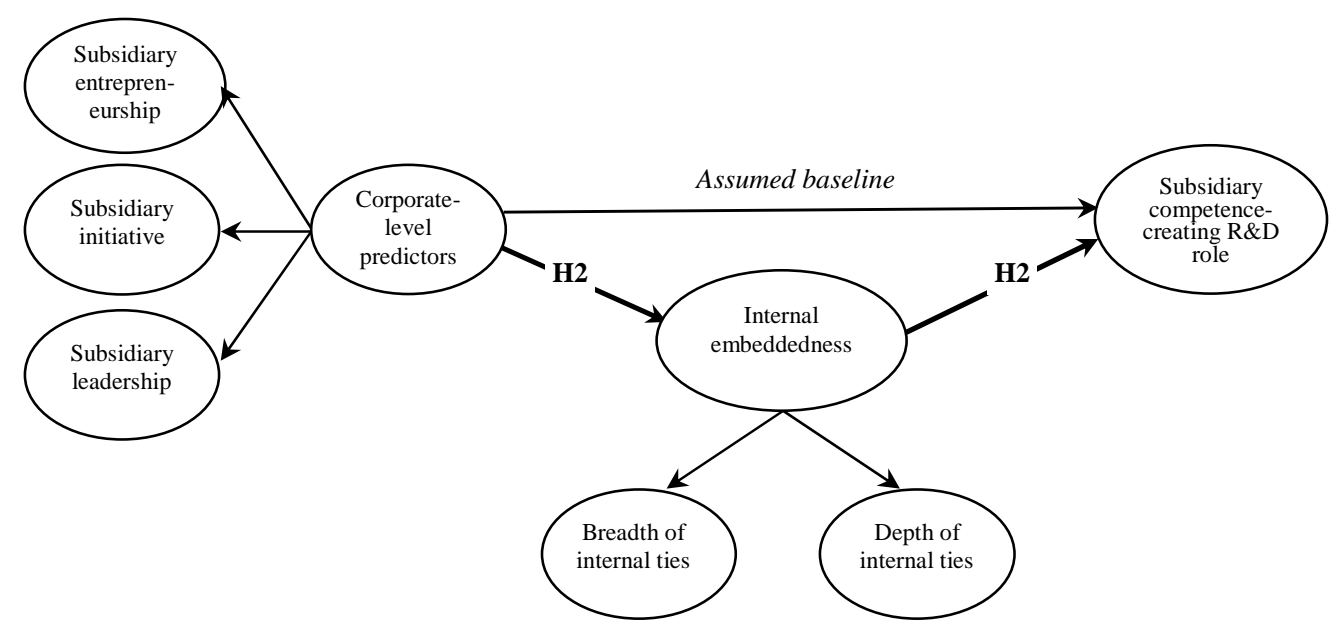

\subsection{Mediating effect of dual network embeddedness: internal and external networks}

The importance of distinct linkages, whether formal or informal, suggests that deciding how and when to build them is a non-trivial choice for subsidiaries (Egbetokun, 2015). Subsidiaries are simultaneously immersed in corporate and country environments in which they seek to build a variety of network ties, which can provide them with the potential to contribute to the firm's overall innovative capacity (Collinson \& Wang, 2012). Their dual embeddedness allows them to access knowledge from a range of sources and to reverse knowledge flows to their internal and external counterparts (Tallman \& Chacar, 2011). This means that subsidiaries sit at the nexus of multiple internal and external networks (Collinson \& Wang, 2012) that are preceded respectively by a number of corporate- and country-level predictors, as outlined in the two previous sections. 
In this sense, the competence-creating $R \& D$ roles are generally associated with sourcing of knowledge abroad, which is conveyed by a subsidiary's business relationships with its external partners (Andersson, Forsgren, \& Pedersen, 2001; Andersson et al., 2002). Strengthening these external network linkages is likely to enhance a subsidiary's contribution to competence development within the MNC (Andersson et al., 2002; 2007) and, at the same time, boost the subsidiary's power position because of the knowledge dependency of other parts of the MNC (Mudambi \& Navarra, 2004). Thus, for a subsidiary to gain access to new knowledge it has to engage more intensively with local partners and in this way it is likely to be rewarded with a competence-creating R\&D mandate. Hence, as a baseline, we assume a positive relationship between external embeddedness and the likelihood of performing a competence-creating $R \& D$ role.

Yet, clearly, the subsidiary is also a member of the MNC network. This means that the subsidiaries are required to be responsible to their host country whilst also meeting the demands of their parent organisation (Forsgren et al., 2005; Reilly \& Scott, 2014). However, striking the right balance is not always easy. Moreover, the resource constraints it faces have opportunity costs in terms of adapting to the external and the internal environment. Limited resources mean that a subsidiary often experiences a trade-off between external and internal embeddedness, which can have two possible outcomes: First, a high degree of external embeddedness may lead a subsidiary to develop context specific capabilities that are not readily applicable in other MNC units (Andersson, Forsgren, \& Holm, 2001). Thus, the subsidiary becomes geographically isolated in the MNC network and its level of contribution to the MNC diminishes. Second, a high degree of internal embeddedness may lead a subsidiary to become heavily dependent for its resources on other parts of the MNC at the expense of sourcing new knowledge through channels of external embeddedness (Andersson et al., 2007). In this case, the subsidiary becomes a receptive unit performing a competence-exploiting $R \& D$ mandate.

Consequently, in order to gain a competence-creating R\&D role a subsidiary must be not only 'externally embedded', operating as an independent actor in its local environment where it establishes relationships so as to learn and assimilate knowledge from the host country environment (Andersson et al., 2002), but also 'internally embedded', integrating itself in the MNC network to transfer its knowledge to the parent company and sister affiliates, insofar as subsidiaries are dependent on the strategic allocation of resources and mandates within the MNC (Meyer et al., 2011).

Consolidation of the subsidiary's R\&D role can only really take place when explicitly acknowledged by corporate headquarters. If a subsidiary's capabilities are not valued, its strategic role will not be recognised and a competence-creating mandate will not be assigned (Birkinshaw \& Hood, 1998). In this second part of the process, a subsidiary must learn to exploit its connectivity within the MNC 
network (Meyer et al., 2011). After accessing local external knowledge, the subsidiary must be able to transfer it internally within the firm so as to gain recognition and to be deemed important for the whole MNC. Increasing intra-organisational knowledge exchange with other units of the MNC is believed to boost a subsidiary's visibility within the whole organisation (Bouquet \& Birkinshaw, 2008), attract headquarters attention (Ambos et al., 2010) and increase its influence over head office's decision making (Mudambi \& Navarra, 2004). More recent contributions show that updated knowledge about their overseas subsidiaries makes headquarters more likely to grant them legitimacy in their R\&D role (Asakawa \& Aoki, 2016).

As a result, the learning effects of external embeddedness need a certain degree of internal embeddedness so that they might contribute to the competence repositories of the entire MNC. Integrating this mediation role of internal embeddedness with that of external embeddedness generates a sequence where country-level predictors impact on its external embeddedness and this in turn influences the subsidiary's competence-creating R\&D role through its internal embeddedness (see Figure 3). Thus:

Hypothesis 3: The relationship between country-level predictors and a subsidiary's competencecreating R\&D mandate is mediated by its dual embeddedness (external and internal embeddedness).

Figure 3. Hypothesis 3

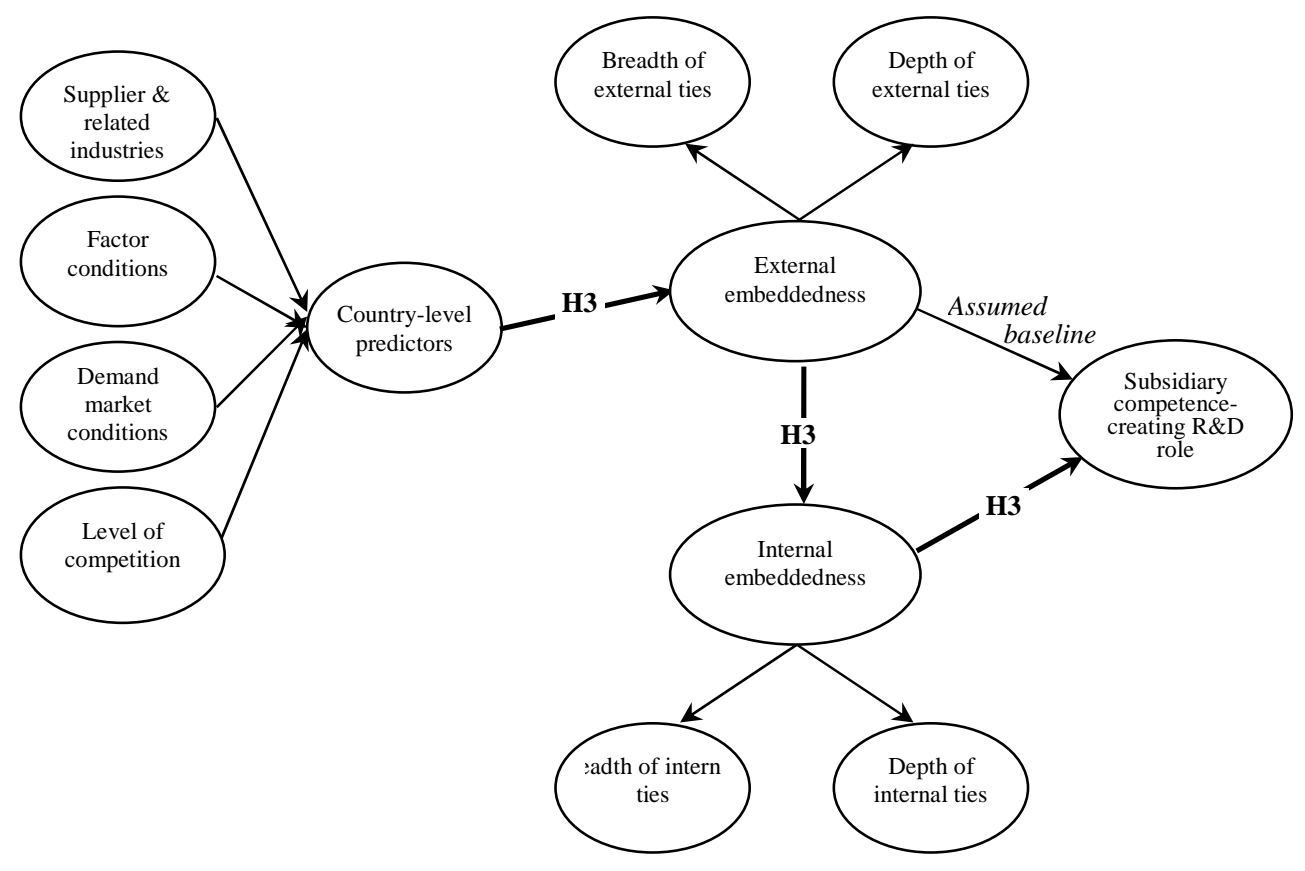

All in all, Figure 4 depicts the final theoretical model integrating the three hypotheses advanced above. In essence, it constitutes a multiple mediation model in which the classical factors used to predict the 
configuration of competence-creating R\&D roles (i.e. 'corporate-level predictors' and 'country-level predictors') are both mediated by the subsidiary's 'internal' and 'external embeddedness'.

Figure 4. Theoretical model

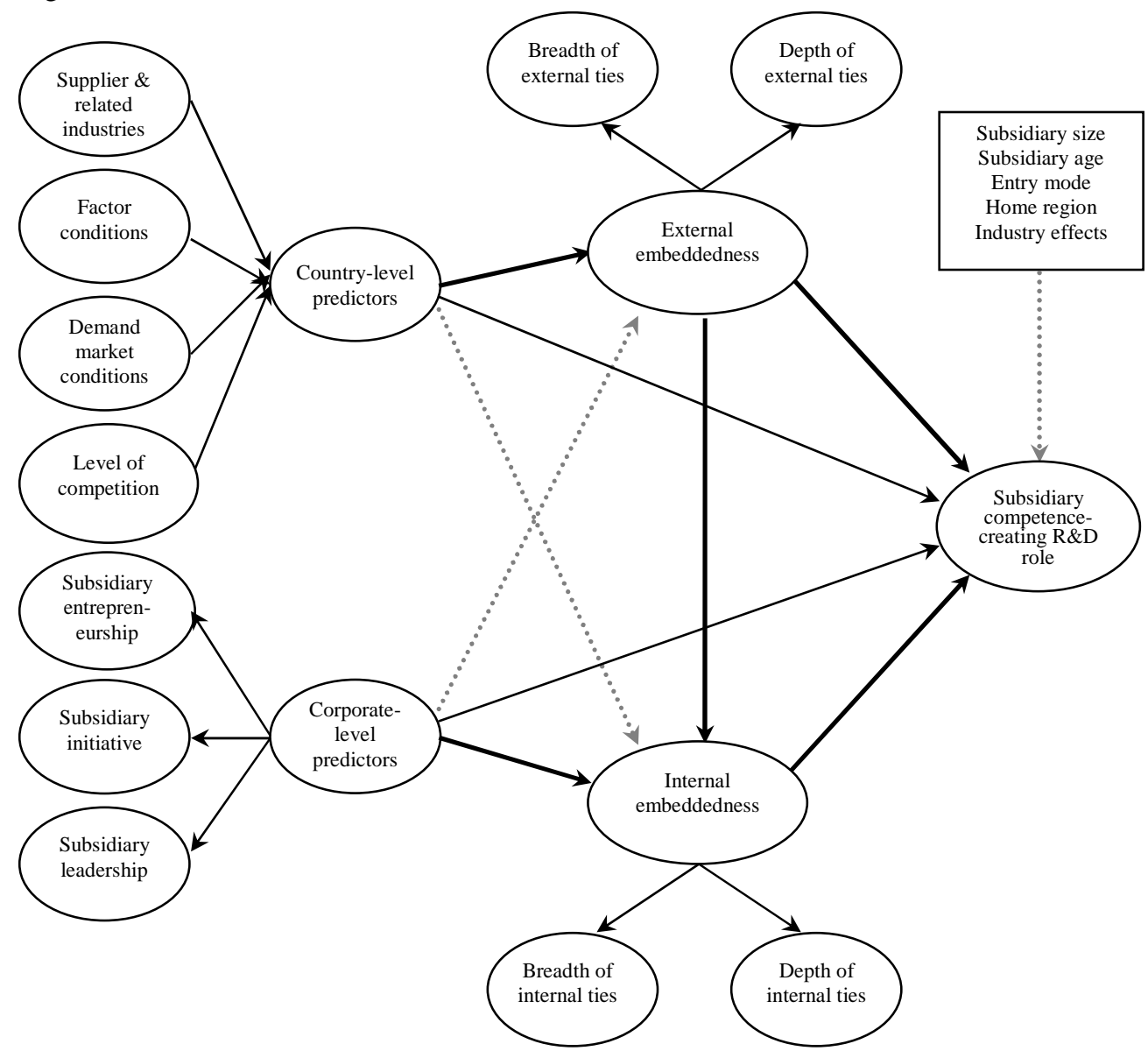

H1: Country-level predictors $\rightarrow$ External embeddedness $\rightarrow$ Subsidiary competence-creating R\&D role H2: Corporate-level predictors $\rightarrow$ Internal embeddedness $\rightarrow$ Subsidiary competence-creating R\&D role H3: Corporate-level predictors $\rightarrow$ External embeddedness $\rightarrow$ Internal embeddedness $\rightarrow$ Subsidiary competence-creating $\mathrm{R} \& \mathrm{D}$ role

\section{METHODS}

\subsection{Questionnaire and data}

Survey instrument. The questionnaire was designed as a part of a broader research project on FDI in Spain sponsored by the Ministry of Industry of the Spanish Government. Before launching the survey, the draft questionnaire was pilot-tested and improved after performing various pre-tests with six experts from both the academic and business worlds. This process resulted in minor changes to ambiguous questions and phrasings so as to enhance comprehensibility. As a result, the final questionnaire included a total of 256 variables measuring a variety of topics concerning the 
configuration of different subsidiary roles. The present study specifically draws on measures of external embeddedness, internal embeddedness and R\&D functional area.

Target population and sampling. The population of this study consists of foreign-owned subsidiaries with productive activity located in Spain. In the absence of registers or directories of this type of units, we constructed the sample frame using data assembled from the annual directory of firms compiled by the Spanish Industrial Journal, Fomento de la producción, and the data base Analysis System of Iberian Balances (SABI) compiled by Informa. Together they monitor more than 200,000 Spanish companies based on information contained in the Commercial Registries, thus covering more than $95 \%$ of the existing population.

We narrowed the companies down by defining foreign-owned subsidiaries as local affiliates whose parent companies held at least 51 percent of their ownership. After correcting for any discrepancies, inaccuracies or out-dated information through the triangulation of the data with other sources (including industry publications, company reports, newspaper articles, etc.), a census of 1,072 foreignowned industrial firms were identified in Spain.

Data collection and respondents. The second stage involved the mailing of the CEOs of the aforementioned 1,072 subsidiaries. The CEO was selected as our target respondent on the basis of their assumed knowledge of the firm's strategic profile (Frost et al., 2002). The first survey mailing was sent out in June 2008, followed up with a reminder and a replacement questionnaire (where necessary) in September 2008. Likewise, a large call round was conducted after every mailing. All in all, a total of 125 questionnaires were returned, which is within the normal range for surveys of MNC subsidiaries with high-level executives as respondents (Harzing \& Noorderhaven, 2006).

The number of usable responses was reduced to 111 , either because the subsidiary reported no R\&D activity at all or for reasons of missing data, giving an effective response rate of $10.35 \%$. Nonresponse bias was checked by comparing the number of employees and the industry (based on twodigit NACE classification) of the respondent subsidiaries with those of the non-respondents. The tstatistic was used to test the non-response bias for the number of employees (in log scale), as the normally distributed quantitative variable, and the Chi-square test for the economic sector, as the nominal variable. No significant differences were found between respondents and non-respondents ( $\mathrm{p}$ value $=0.594 ; \mathrm{p}$-value $=0.377$, respectively).

The final sample covers more than 20 different types of manufacturing industry (based on two-digit NACE classification), with subsidiaries from the chemical (18.2\%), pharmaceutical (12.7\%) and metal products, machinery and equipment (10.0\%) industries dominating the sample. Within the sample, 
subsidiaries vary considerably in size (ranging from 5 to 7,406 employees with an average of 394), age (ranging from 2 to 118 years with an average of 35), internationalisation (ranging from 0 to 96\% foreign sales with an average of $28.34 \%$ ) and $R \& D$ budgets (ranging from $€ 0.02$ million to $€ 41.33$ million with an average of $€ 3.92$ million). Parent company nationality is also varied (with 18 nationalities being represented): $73.64 \%$ are of European origin, $20.00 \%$ North American, and 5.45\% Asian. This guarantees a diverse sample in terms of industry, size, age and internationalisation, and hence we minimise the number of sources of extraneous variance and systematic bias.

\subsection{Measures}

The measures used in this paper, in line with previous studies, are based on elements captured from an initial literature review, while we extend prior operationalisations by purposely customizing them to this specific research project. Table 1 provides a summary of the constructs used.

Table 1. Constructs and measures

\begin{tabular}{|c|c|}
\hline CONSTRUCT/INDICATOR & DEFINITION \\
\hline COUNTRY-LEVEL PREDICTORS & $\begin{array}{l}\text { Respondents assessed the strength of the following aspects of the } \\
\text { business environment in which their subsidiary competes. } \\
\text { (scale anchored as } 1=\text { not strong at all; } 7=\text { very strong) }\end{array}$ \\
\hline $\begin{array}{l}\text { Level of competition } \\
\text { - Domestic rivalry } \\
\text { - Firm strategy } \\
\end{array}$ & $\begin{array}{l}\text { - High intensity of domestic rivalry } \\
\text { - High intensity in differentiation competitive strategy }\end{array}$ \\
\hline $\begin{array}{l}\text { Demand market conditions } \\
\text { - Key customers } \\
\text { - New market niches } \\
\end{array}$ & $\begin{array}{l}\text { - Sophisticated and demanding customers } \\
\text { - Potential new market niches for innovative products }\end{array}$ \\
\hline $\begin{array}{l}\text { Factor conditions } \\
\text { - Raw materials } \\
\text { - Skilled/cheap labour }\end{array}$ & $\begin{array}{l}\text { - Availability of raw materials } \\
\text { - Availability of skilled/cheap labour }\end{array}$ \\
\hline $\begin{array}{l}\text { Supplier and related industries } \\
\text { - Supply industries } \\
\text { - Complementary \& supporting industries } \\
\end{array}$ & $\begin{array}{l}\text { - Quality of supply industries } \\
\text { - Existence of complementary \& supporting industries }\end{array}$ \\
\hline CORPORATE-LEVEL PREDICTORS & $\begin{array}{l}\text { Respondents indicated to what extent the following statements } \\
\text { correspond to their subsidiary. } \\
(1=\text { strongly disagree; } 7=\text { strongly agree })\end{array}$ \\
\hline $\begin{array}{l}\text { Subsidiary entrepreneurship } \\
\text { - Proactiveness } \\
\text { - HQs risk-taking encouragement }\end{array}$ & $\begin{array}{l}\text { - Managers consistently engage in new ventures even if they are } \\
\text { uncertain. } \\
\text { - There is encouragement for calculated risk }\end{array}$ \\
\hline $\begin{array}{l}\text { Subsidiary initiative } \\
\text { - Beyond mandate } \\
\text { - Legitimacy } \\
\text { - Enhancement } \\
\text { - Obeying orders (item dropped) }\end{array}$ & $\begin{array}{l}\text { - The subsidiary has developed competences beyond the mandate } \\
\text { assigned by headquarters. } \\
\text { - Managerial initiatives and dissent are viewed as legitimate } \\
\text { - Managers have initiative to enhance local value-added activities. } \\
\text { - The subsidiary only executes the decisions taken in other units of the } \\
\text { group }\end{array}$ \\
\hline $\begin{array}{l}\text { Subsidiary leadership } \\
\text { - Decision making participation } \\
\text { - Good political relationships }\end{array}$ & $\begin{array}{l}\text { - Subsidiary managers actively participate in corporate decision- } \\
\text { making committees } \\
\text { - Subsidiary senior managers have fostered good political relations }\end{array}$ \\
\hline
\end{tabular}


- Managers' track record

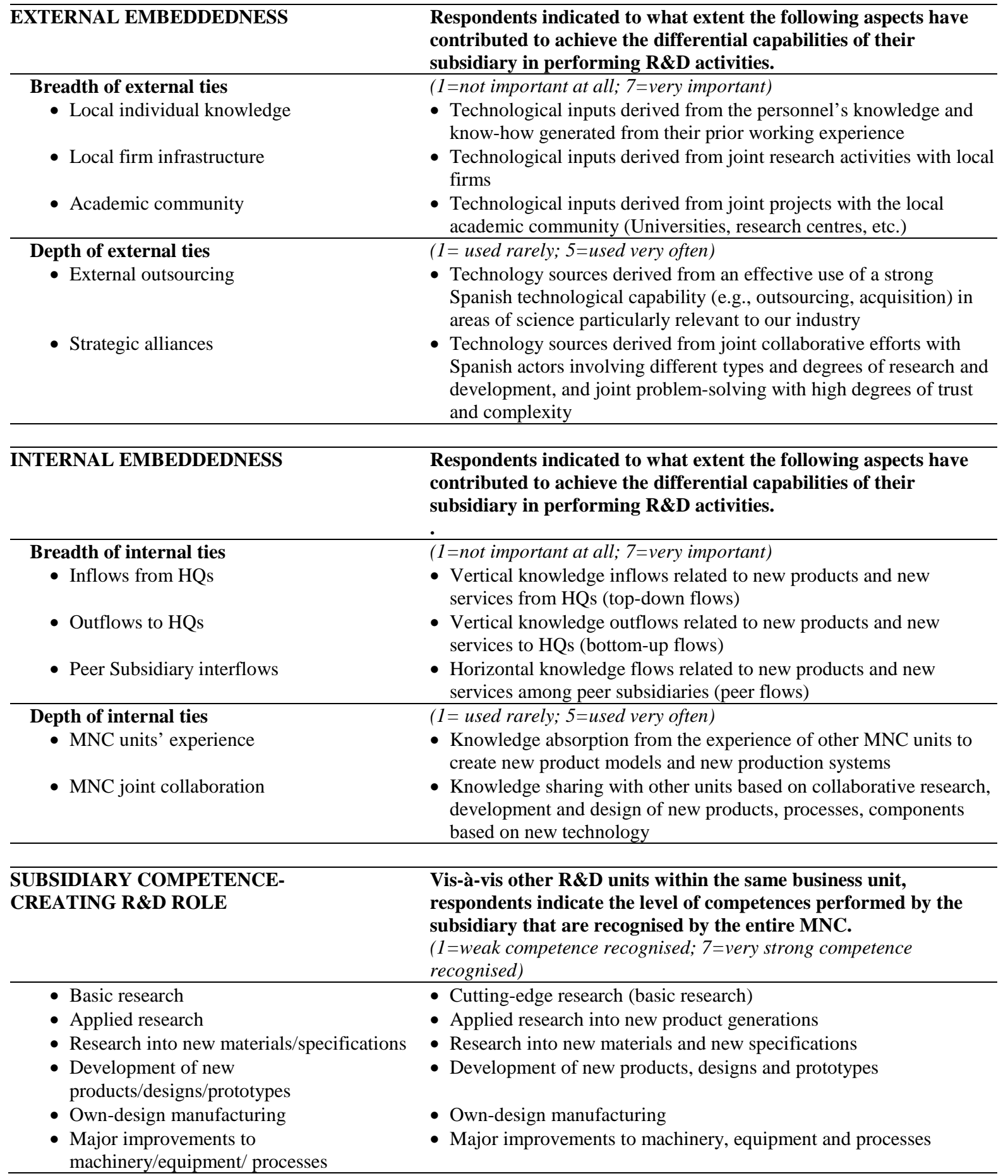
subsidiary in performing R\&D activities.

=not important at all; $7=$ very importan

firms

$1=$ used rarely; $5=$ used very often areas of science particularly relevant to our industry

Technology sources derived from joint collaborative efforts with ty actors involving different types and degrees of research and high degrees of trust

Respondents indicated to what extent the following aspects have contributed to achieve the differential capabilities of their

$1=$ not important at all; $7=$ very important services from HQs (top-down flows)

Vertical knowledge outflows related to new products and new (bottom-up flows) services among peer subsidiaries (peer flows)

( $1=$ used rarely; $5=$ used very often $)$

Knowledge absorption from the experience of other MNC units to Knew product models and new production system development and design of new products, processes, components

is-à-vis other $R \& D$ units within the same business unit, ents indicate the level of competences perforn recognised)

- Applied rese

- Applied research into new product generations

- Research into new materials and new specifications

- Own-design manufacturing machinery/equipment/ processes with their counterparts and bosses in head office and sister affiliates

- The subsidiary has a history of strong, internally respected leaders

Country-level predictors. The configuration of the environment was measured using eight items, reflecting the subsidiary manager's perception of different aspects of the host country. Building on the main elements of Porter's (1990) diamond model and the scale developed by Frost et al. (2002), respondents were asked to assess the business environment in which they compete: 'level of competition'; 'demand market conditions'; 'factor conditions'; and availability of 'supplier and related industries'. In line with Venaik, Midgley, \& Devinney's (2005) recommendations, we specified this 
measure as a reflective first-order, formative second-order construct (see Figure 4). They argue that environmental pressures are too diverse to covary and to be considered typical 'reflective' onedimensional latent constructs, advocating 'for more pressure dimensions and for measuring these by the formative indexes' (Venaik et al., 2005: 663).

Corporate-level predictors. The corporate-level variable was constructed from eight questionnaire items specified as statements to which managers indicated agreement. This set of measures was assembled from multiple contributions in order to capture not only subsidiary choices but also headquarters perceived stance towards them. Initially, this variable was modelled as a single first-order factor; however, the number of items fell in the course of Factor Analysis in the PLS, suggesting the existence of underlying dimensions. The first dimension embraces entrepreneurial orientation using measures of risk-taking encouragement and subsidiary proactiveness inspired by Covin \& Slevin (1989) and Miller \& Friesen (1982). The second dimension assesses subsidiary initiative based on Roth \& Morrison (1992) and Birkinshaw's (1997) scales. The third dimension captures subsidiary leadership based on Birkinshaw et al.'s (1998) measure. Finally, the corporatelevel variable was specified as a reflective-reflective second-order construct.

Dual-embeddedness. Internal and external technical embeddedness were captured using a total of ten indicators. First, as regards the 'breadth' of subsidiary ties, respondents indicated the importance of their interactions with different types of agents (either local actors or corporate counterparts) for the development of the subsidiary's R\&D competences. In the external embeddedness category, in line with Asmussen, Pedersen, \& Dhanaraj (2009), we use the network links specific to the technical environment, consisting of labour with industry-specific skills, local research institutions, and related industries (three items). In the internal embeddedness category, the items cover knowledge sourcing linked to the corporate agents, namely, the focal subsidiary, the headquarters and the peer subsidiary units (three items) (Figueiredo, 2011). Second, the strength of a subsidiary's network relationships was captured by asking respondents about their 'depth' of engagement in certain knowledge-based linkages that require high degrees of commitment, trust and reciprocity and which embody the concept of embeddedness (Dacin, Ventresca, \& Beal, 1999). In the case of external embeddedness, we included outsourcing and alliances/cooperation linkages (Manolopoulos, Dimitratos, Young, \& Lioukas, 2009; Dimitratos, Liouka \& Young, 2014); while for internal embeddedness, we refer to linkages for leveraging the experience of other units and joint collaborative efforts (two items) (Minbaeva, Pedersen, Björkman, Fey, \& Park, 2003; Monteiro, Arvidsson, \& Birkinshaw, 2008). Both the internal and external embeddedness variables were specified as reflective second-order constructs, each loading strongly on two dimensions that fit the concepts of breadth (diversity of agents) and depth (commitment and trust) of the subsidiary's patterns of contacts with its partners as proposed by Andersson et al. (2002). 
Subsidiary competence-creating $R \& D$ role. The subsidiary competence-creating $\mathrm{R} \& \mathrm{D}$ role construct comprises six items measuring, from the subsidiary manager's perspective, the level of capabilities in different R\&D activities performed by the subsidiary and recognized by the entire MNC. Our aim here, in keeping with Birkinshaw \& Hood (1998), is to focus on the subsidiary's mandate and its underlying capabilities. This variable, specified as a first-order construct, captures the subsidiary's recognised capabilities for undertaking its competence-creating R\&D role. As such, it is an adaptation of the measure of a firm's technological capabilities as proposed by Iammarino, PadillaPerez, \& Von Tunzelmann (2008), but here we consider only the advanced category of capabilities as descriptors of a competence-creating $R \& D$ role (see Table 1 for specific details).

Control variables. In order to control for effects other than those hypothesised, we used several control variables which we drew from the previous literature and used to control for their influence on knowledge transfer and mandate allocation. First, we introduced 'subsidiary size' measured as the number of employees in the focal subsidiary (Foss \& Pedersen, 2002; Bouquet \& Birkinshaw, 2008) and 'subsidiary age' computed as the number of years the subsidiary had been in operation (Håkansson \& Snehota, 1995; Yamin \& Andersson, 2011). Second, to ensure that 'entry mode' is not driving the results, we used a dummy variable as a control for the formation of the subsidiary (1=greenfield investments and $0=$ otherwise) (Belderbos, 2003; Björkman, BarnerRasmussen, \& Li, 2004). Third, following Rugman \& Verbeke's (2004) regionalisation theory, we introduced a dummy variable, 'home region', for similar vs. different locations with respect to the continent on which the subsidiary's headquarters is are located, in this case the EU. Fourth, we controlled for 'industry effects' (Gupta \& Govindarajan, 2000; Frost et al., 2002) creating a dummy variable based on two-digit NACE classification subsequently collapsed into OECD technology and knowledge-intensity industry classifications. Finally, to guard against incorrect conclusions, we also estimated two non-hypothesised paths between 'country-level predictors' and 'internal embeddedness' and between 'corporate-level predictors' and 'external embeddedness'. Thus, in these specific relationships, the independent variables act as controls.

\section{DATA ANALYSIS TECHNIQUE AND RESULTS}

A partial least square (PLS) approach to structural equation modelling (Chin, 1998; Wold, 1982) was used to test the hypotheses, specifically we used SmartPLS 2.0 software (Ringle, Wende, \& Will, 2005). For the analysis conducted here, this technique is preferable for several reasons: First, as dual embeddedness is still at an early stage of development, the regression-based approach of PLS is more appropriate than the use of covariance-based models, since the former is better suited to 'predictive research' models, that is, exploratory studies (Chin, 2010) such as the one reported herein. Predictions 
are achieved by 'extracting from the predictors a set of orthogonal factors called latent variables which have the best predictive power' (Abdi, 2010: 97). Second, the research model contains both reflective and formative constructs, to which PLS is particularly suited (Diamantopoulos \& Winklhofer, 2001; Jarvis, MacKenzie, \& Podsakoff, 2003). Third, PLS is also particularly useful for forecasting a set of dependent variables from a very large set of independent variables, i.e., predictors (Abdi, 2010). In our model, four of the five main constructs are second-order constructs measured using eleven dimensions and interwoven with a set of mediations. Such a complex model specification corroborates the suitability of PLS, given its robustness in dealing with complex models of limited sample size (Reinartz, Haenlein, \& Henseler, 2009) and skewed data (Ringle, Götz, Wetzels, \& Wilson, 2009; Wilden, Gudergan, Nielsen, \& Lings, 2013).

The PLS estimates are reported in two stages following the recommendations of Chin (2010). In the first stage, we assess the psychometric properties of the measurement model, while in the second stage we provide evidence supporting the structural model as exemplified by the hypothesis. Bootstrap percentile confidence intervals (setting the number of bootstrap samples equal to 5000) were constructed to assess the significance of the parameter estimates (Preacher \& Hayes, 2004; Chin, 2010).

\subsection{Psychometric properties of the measurement model}

As the second-order latent variables in the model encompass both reflective and formative constructs, the two-stage approach, also known as the latent variable score method (Ringle, Sarstedt, \& Straub, 2012; Wetzels, Odekerken-Schroder, \& van Oppen, 2009), was adopted to specify the hierarchical latent variables. In both first-order and second-order reflective measurement models, psychometric properties proved to be optimal with reference to the reliability and validity attributes of the item scales used. Item standardised loadings are equal to at least 0.707 (Carmines \& Zeller, 1979), except for 'key customers', 'decision making participation', and 'external outsourcing' items, which were retained in the model, since they are over the minimum acceptable value of 0.55 suggested by Falk \& Miller (1992) for initial stages of research development (Chin, 1998) ${ }^{1}$. Further, we find all factor loadings to be significant at the 0.01 level (based on a Student $t(4999)$ distribution, two-tailed test). Composite reliabilities exceeded the benchmark of 0.7 for exploratory research suggested by Nunnally (1978) (Tables 2 \& 3) and convergent validity in terms of average variance extracted (AVE), exceeds the 0.5 threshold recommended by Fornell \& Larcker (1981). Moreover, comparison of these reliabilities with inter-construct correlations demonstrates adequate discriminant validity (Fornell \& Larcker, 1981). This can be seen in Tables 2 and 3, where the AVE for each construct is much larger than the squared correlation between two constructs.

\footnotetext{
${ }^{1}$ Item standardized loadings are available upon request from the authors.
} 
Table 2. Validation of the first-order measurement model. Construct reliability, convergent and discriminant validity

\begin{tabular}{|c|c|c|c|c|c|c|c|c|c|c|c|c|c|}
\hline & 1 & 2 & 3 & 4 & 5 & 6 & 7 & 8 & 9 & 10 & 11 & 12 & $\begin{array}{c}\text { Composite } \\
\text { reliability }\end{array}$ \\
\hline 1. Level of competition & 0.683 & & & & & & & & & & & & 0.809 \\
\hline 2. Demand market conditions & 0.067 & 0.632 & & & & & & & & & & & 0.762 \\
\hline 3. Subsidiary entrepreneurship & 0.004 & 0.034 & 0.738 & & & & & & & & & & 0.849 \\
\hline 4. Breadth of external ties & 0.276 & 0.055 & 0.007 & 0.700 & & & & & & & & & 0.875 \\
\hline 5. Depth of external ties & 0.028 & 0.059 & 0.022 & 0.072 & 0.653 & & & & & & & & 0.784 \\
\hline 6. Factor conditions & 0.109 & 0.013 & 0.004 & 0.213 & 0.004 & 0.738 & & & & & & & 0.849 \\
\hline 7. Subsidiary initiative & 0.004 & 0.001 & 0.236 & 0.005 & 0.007 & 0.000 & 0.603 & & & & & & 0.819 \\
\hline 8. Breadth of internal ties & 0.060 & 0.041 & 0.105 & 0.088 & 0.111 & 0.046 & 0.020 & 0.684 & & & & & 0.866 \\
\hline 9. Depth of internal ties & 0.024 & 0.048 & 0.132 & 0.017 & 0.153 & 0.064 & 0.051 & 0.315 & 0.877 & & & & 0.935 \\
\hline 10. Subsidiary leadership & 0.032 & 0.033 & 0.311 & 0.017 & 0.003 & 0.002 & 0.371 & 0.057 & 0.044 & 0.510 & & & 0.753 \\
\hline 11. Subsidiary competence-creating role & 0.204 & 0.056 & 0.078 & 0.247 & 0.119 & 0.139 & 0.041 & 0.380 & 0.248 & 0.056 & 0.618 & & 0.906 \\
\hline 12. Supplier \& related industries & 0.185 & 0.148 & 0.001 & 0.242 & 0.059 & 0.171 & 0.005 & 0.080 & 0.066 & 0.024 & 0.140 & 0.627 & 0.769 \\
\hline
\end{tabular}

Note: Diagonal represents the average variance extracted; while below the diagonal the shared variance (squared correlations) is represented.

Table 3. Validation of the second-order measurement model. Composite reliability, convergent and discriminant validity

\begin{tabular}{|c|c|c|c|c|c|c|}
\hline & 1 & 2 & 3 & 4 & 5 & $\begin{array}{l}\text { Construct } \\
\text { reliability }\end{array}$ \\
\hline 1. Corporate-level predictors & 0.694 & & & & & 0.871 \\
\hline 2. Country-level predictors & 0.008 & n.a. & & & & n.a. \\
\hline 3. External embeddedness & 0.020 & 0.350 & 0.628 & & & 0.770 \\
\hline 4. Internal embeddedness & 0.126 & 0.129 & 0.149 & 0.780 & & 0.876 \\
\hline 5. Subsidiary competence-creating role & 0.085 & 0.278 & 0.295 & 0.405 & 0.618 & 0.906 \\
\hline
\end{tabular}

Note: Diagonal represents the average variance extracted; while below the diagonal the shared variance (squared correlations) are represented.

For the formative second-order construct 'country-level predictors', psychometric properties are interpreted using weights and their statistical significance. Except for 'demand market conditions', the contribution of all dimensions to the formative measure is significant at least at the 0.05 level. Nevertheless, 'demand market conditions' should be interpreted as 'absolutely important' (Hair, Sarstedt, Pieper, \& Ringle, 2012) and retained in the model, since while their outer weight is insignificant, their outer loading has a value above 0.5 (specifically 0.51 ). Additionally, we took the precaution to test for multicollinearity, as it may inflate bootstrap standard errors in formative models (Cenfetelli \& Bassellier, 2009). An inspection of the variance inflation factor (VIF) using SPSS 20.0 for Windows does not raise any concerns about multicollinearity, as it is well below the cut-off value of 5 (Kleinbaum, Kupper, \& Muller, 1988). Taken together, these results provide sufficient confidence that the measurement model used in this research is reliable and valid. 


\subsection{Common method bias assessment}

Common method variance bias was evaluated ex post to check for biases not minimised by the survey design. We took the ad hoc statistical approach suggested by Podsakoff, MacKenzie, Lee, \& Podsakoff (2003) and adapted for use with PLS by Liang, Saraf, Hu, \& Xue (2007). Specifically, a latent 'method' factor with all the indicators was added to the structural model. As a result, the indicator loadings on the hypothesised constructs are all significant (based on a Student $\mathrm{t}(4999)$ distribution, two-tailed test), whereas, with only one exception ('Development of new products/designs/prototypes'), all of their loadings on the method factor are non-significant. The variance in the indicators, explained by their hypothesised constructs (on average 0.641), are substantially larger than those explained by the method factor (on average 0.016 ). The above results show that the common method bias was unlikely to be a serious concern for this study.

\subsection{Structural model evaluation}

The theoretical model proposed explains more than $50 \%$ of the variance of the final endogenous variable predicted, i.e. 'subsidiary competence-creating $R \& D$ mandate' $\left(R^{2}=0.58\right)$, which can be rated as a 'moderate-substantial' predictive capacity (Chin, 1998). A power analysis was performed using G*Power 3 (Faul, Erdfelder, Lang, \& Buchner, 2007) to test whether our sample size guaranteed power for the $\mathrm{R}^{2}$ deviation from zero greater than 80 percent for the model depicted in Figure 4 (Cohen, 1988). The power achieved was greater than 90 percent. Also, the Stone-Geisser $Q^{2}$ statistic (Geisser, 1974; Stone, 1974) is higher than zero for the three endogenous constructs, suggesting that the model has predictive relevance (see Model 1 in Table 4). Finally, structural path coefficients and, in particular, their significance and size demonstrated that 'subsidiary competence-creating $R \& D$ mandate' is directly and positively influenced by both 'internal' and 'external embeddedness', which in turn, are directly and positively influenced by the 'corporate-level predictors' and 'country-level predictors' respectively, which points to the existence of possible mediations. These paths are represented in Figure 5.

The control variables fall into two sets. The first set comprises the standard, subsidiary-specific variables that control for firm heterogeneity ('subsidiary age', 'subsidiary size', 'home region', 'entry mode' and 'industry effects'). Given the insignificant effects of these control variables, we followed the principle of parsimony and excluded them from all further analyses (Berghman, Matthyssens, Streukens, \& Vandenbempt, 2013; Scott et al., 2010). The second set is the more relevant from the network-based perspective, and comprises the effect of 'corporate-level predictors' on 'external embeddedness' and 'country-level predictors' on 'internal embeddedness'. In both cases, no 
significant effect was found. Nevertheless, given that the confidence interval of the second control is very close to zero, we retained it in the model.

For the sake of caution, an additional analysis, reversing the line of causality between 'external embeddedness' and 'internal embeddedness', was undertaken (see Model 2 in Table 4). Although research on network embeddedness has largely established the causality direction as specified in our model, the reverse impact between these variables has never explicitly been shown. Apart from the predictable variation in the variance explained by these variables and the small changes in the paths throughout the model, the shift in path direction between 'external embeddedness' and 'internal embeddedness' resulted in a non-significant path. This verification corroborates the adequacy of the line of causality as depicted in our model.

Table 4. Structural model assessment and reverse causality between external and internal embeddedness)

\begin{tabular}{|c|c|c|c|c|c|c|c|c|}
\hline \multirow{3}{*}{ PATHS } & \multicolumn{4}{|c|}{ MODEL 1} & \multicolumn{4}{|c|}{ MODEL 2} \\
\hline & \multirow{2}{*}{$\begin{array}{l}\text { Path } \\
\text { coefficient }\end{array}$} & \multicolumn{2}{|c|}{$\begin{array}{l}\text { SIGNIFICANCE } \\
\text { (bootstrapping) }\end{array}$} & \multirow[t]{2}{*}{$\mathrm{R} 2$} & \multirow{2}{*}{$\begin{array}{l}\text { Path } \\
\text { coefficient }\end{array}$} & \multicolumn{2}{|c|}{$\begin{array}{l}\text { SIGNIFICANCE } \\
\text { (bootstrapping) }\end{array}$} & \multirow[t]{2}{*}{$\mathrm{R} 2$} \\
\hline & & t-value & CI $(95 \%)$ & & & t-value & CI $(95 \%)$ & \\
\hline Effects on external embeddedness & & & & 0.358 & & & & 0.391 \\
\hline - Country level predictors $\rightarrow$ External embeddedness & 0.584 & $8.339 * *$ & {$[0.445,0.716]$} & & 0.534 & $6.204 * *$ & {$[0.355,0.691]$} & \\
\hline Effects on internal embeddedness & & & & 0.267 & & & & 0.234 \\
\hline - Corporate level predictors $\rightarrow$ Internal embeddedness & 0.305 & $3.756^{* *}$ & {$[0.142,0.461]$} & & 0.325 & $4.201 * *$ & {$[0.173,0.473]$} & \\
\hline - External embeddedness $\rightarrow$ Internal embeddedness & 0.226 & $2.061 *$ & {$[0.002,0.428]$} & & --- & --- & --- & \\
\hline - Internal embeddedness $\rightarrow$ External embeddedness & --- & --- & --- & & 0.176 & 1.790 & {$[-0.026,0.360]$} & \\
\hline Effects on subsidiary R\&D contributory role & & & & 0.583 & & & & 0.583 \\
\hline - Corporate level predictors $\rightarrow$ Subsidiary R\&D cont. role & 0.104 & 1.194 & {$[-0.061,0.277]$} & & 0.103 & 1.181 & {$[-0.070,0.270]$} & \\
\hline - Country level predictors $\rightarrow$ Subsidiary R\&D cont. role & 0.208 & $2.485 *$ & {$[0.051,0.381]$} & & 0.205 & $2.441 *$ & {$[0.051,0.383]$} & \\
\hline - External embeddedness $\rightarrow$ Subsidiary R\&D cont. role & 0.234 & $2.559 *$ & {$[0.052,0.410]$} & & 0.236 & $2.570 *$ & {$[0.053,0.412]$} & \\
\hline - Internal embeddedness $\rightarrow$ Subsidiary R\&D cont. role & 0.415 & $5.476^{* *}$ & {$[0.265,0.563]$} & & 0.417 & $5.620 * *$ & {$[0.265,0.563]$} & \\
\hline \multicolumn{9}{|l|}{ Control variables on subsidiary R\&D contributory role } \\
\hline - Industry effects $\rightarrow$ Subsidiary R\&D cont. role & 0.126 & 1.983 & {$[-0.005,0.246]$} & & 0.124 & 1.922 & {$[-0.004,0.248]$} & \\
\hline - Subsidiary age $\rightarrow$ Subsidiary R\&D cont. role & 0.141 & 1.825 & {$[-0.013,0.288]$} & & 0.140 & 1.795 & {$[-0.016,0.290]$} & \\
\hline - Subsidiary size $\rightarrow$ Subsidiary R\&D cont. role & 0.036 & 0.625 & {$[-0.086,0.149]$} & & 0.037 & 0.660 & {$[-0.074,0.144]$} & \\
\hline - Home region $\rightarrow$ Subsidiary R\&D cont. role & 0.036 & 0.574 & {$[-0.157,0.089]$} & & -0.034 & 0.535 & {$[-0.157,0.091]$} & \\
\hline - Entry mode $\rightarrow$ Subsidiary R\&D cont. role & 0.004 & 0.064 & {$[-0.129,0.135]$} & & 0.003 & 0.045 & {$[-0.130,0.132]$} & \\
\hline \multicolumn{9}{|l|}{ Control variables on embeddedness } \\
\hline - Corporate level predictors $\rightarrow$ External embeddedness & 0.089 & 1.225 & {$[-0.058,0.227]$} & & 0.030 & 0.387 & {$[-0.122,0.181]$} & \\
\hline - Country level predictors $\rightarrow$ Internal embeddedness & 0.198 & 1.891 & {$[-0.001,0.409]$} & & 0.330 & $4.249 * *$ & {$[0.184,0.488]$} & \\
\hline
\end{tabular}

Note: $\mathrm{CI}=$ Confidence Interval; ${ }^{* *} p<0.01 ; * p<0.05$ (based on a Student $\mathrm{t}(4999)$ distribution, two-tailed test). 
Figure 5. Path values and variance explained

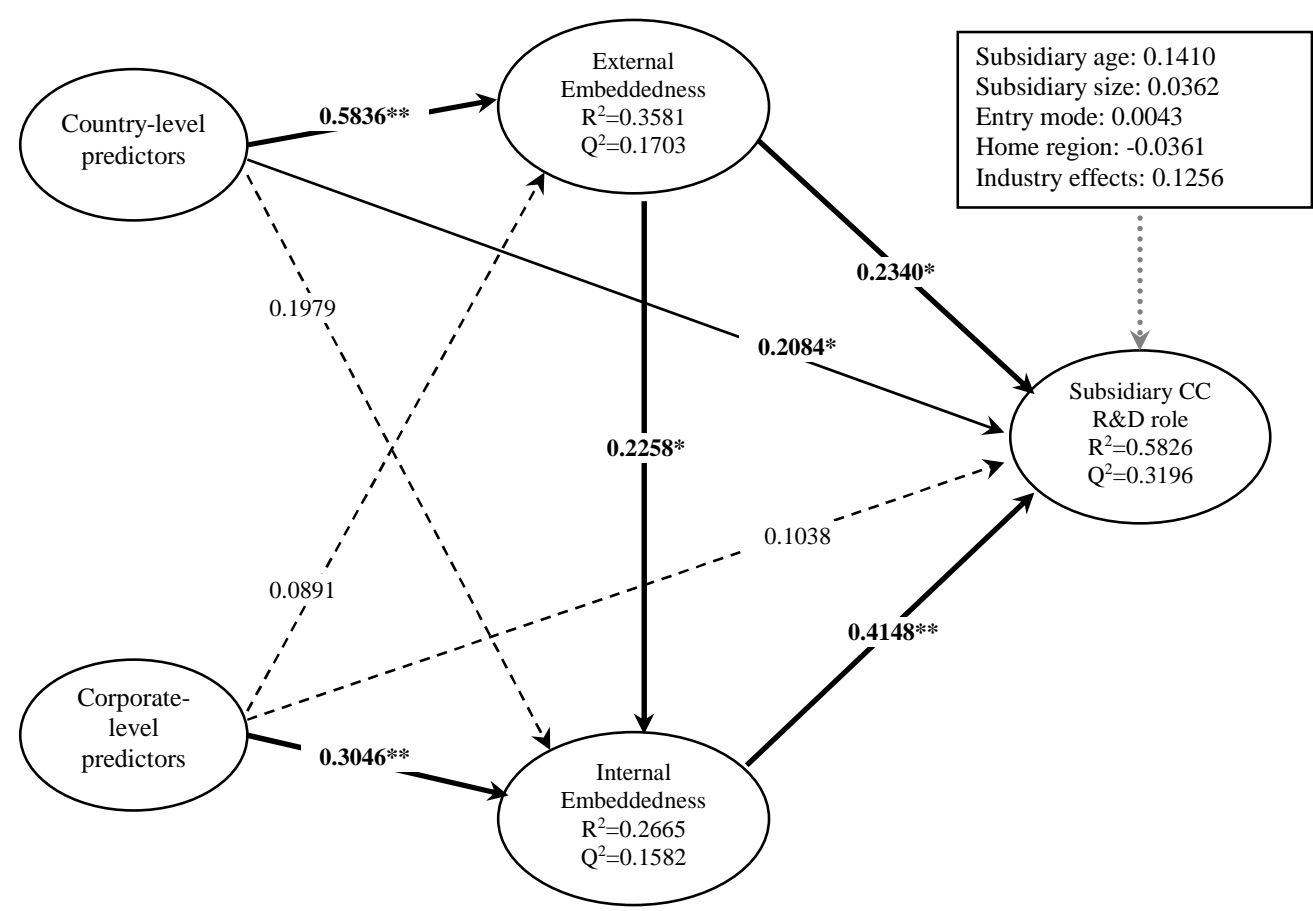

Note: ${ }^{* *} p<0.01 ; * p<0.05$ (based on a Student t(4999) distribution, two-tailed test).

\subsection{Results of the post hoc assessment of mediating effects}

Because our theoretical model involves multiple mediation hypotheses and requires testing indirect effects, either in parallel or linked serially in a cause sequence, we applied Hayes' (2012) PROCESS macro in SPSS 20 for testing serial multiple mediator models (Hayes, Preacher, \& Myers, 2011). Moreover, this method uses bias-corrected bootstrap for testing mediating effects, which it performs better than Baron \& Kenny (1986) and Sobel (1982) in small to moderate samples in terms of both its statistical power and Type I error rate (MacKinnon, Lockwood, \& Williams, 2004; Preacher \& Hayes, 2008).

The macro also makes it possible to include more than one independent variable, each of which can be tested in a complementary model, and to control simultaneously the non-hypothesised effects of 'corporate-' and 'country-level predictors'. In each model, we chose one of the independent variables (either the 'corporate-level predictors' or 'country-level predictors') as the primary independent variable to be examined, and treated the other as covariates for that test (c.f. Sun, 2010). In this sense, Table 5 shows the results of the post hoc assessment of these mediating effects.

The first complementary model is specified with the 'corporate-level predictors' as the independent variable (Model 1 in Table 5) and the 'country-level predictors' treated as a covariate. As can be seen, 'corporate-level predictors' have a significant total effect on the 'subsidiary competence-creating 
$R \& D$ mandate' $\left(\beta=0.247 * *, C_{.95}=[0.091,0.402]\right)$, which confirms our assumed baseline relationship. When the mediators (i.e. 'external embeddedness' and 'internal embeddedness') are introduced, the 'corporate-level predictors' no longer have a significant direct effect on the 'subsidiary competencecreating R\&D mandate' $\left(\beta=0.084, \mathrm{CI}_{.95}=[-0.054,0.223]\right)$. Further, the total indirect effect is different from zero since the confidence interval does not contain zeros $\left(\beta=0.163 ; \mathrm{CI}_{95}=[0.076,0.284]\right)$. An examination of the specific indirect effects indicates that 'internal embeddedness' is the only significant mediator $\left(\beta=0.134 ; \mathrm{CI}_{95}=[0.060,0.242]\right)$. Therefore, we can affirm that 'internal embeddedness' fully mediates the impact of 'corporate-level predictors' on the 'subsidiary competence-creating R\&D mandate', so $\mathrm{H} 2$ is supported.

The second complementary model has the 'country-level predictors' as the independent variable and 'corporate-level predictors' as a covariate (Model 2 in Table 5). In line with these results, 'countrylevel predictors' do have a significant total effect on the 'subsidiary competence-creating R\&D mandate' $\left(\beta=0.507, \mathrm{CI}_{.95}=[0.351,0.662]\right)$, which supports our baseline relationship. When the mediators (i.e. 'external embeddedness' and 'internal embeddedness') are introduced, the effect of 'country-level predictors' directly on the 'subsidiary competence-creating R\&D mandate' becomes significantly smaller in size relative to the total effect $\left(\beta=0.235, \mathrm{CI}_{95}=[0.072,0.398]\right)$, but it remains significant at the $95 \%$ confidence interval. An examination of the specific indirect effects shows that both indirect effects, through 'external embeddedness' and through 'external-internal embeddedness' in a double-step path, act as mediators, since their $95 \%$ confidence interval does not contain zero. In contrast, the specific indirect effect through 'internal embeddedness' does not act as a mediator. This partially supports $\mathrm{H} 1$ and $\mathrm{H} 3$, since both mediating and direct effects coexist and point in the same direction, which means that partial mediations but not full mediations exist.

Finally, a particular feature of these findings is that they can be shown to be robust after controlling for the effects of 'corporate-level predictors' on 'external embeddedness' and 'country-level predictors' on 'internal embeddedness', two indirect effects that were not hypothesised. These results reduce the risk of wrong conclusions being drawn as a consequence of parameter bias due to omitted variables (Judd \& Kenny, 1981). 
Table 5. Summary of the results from the post hoc assessment of mediating effects

\begin{tabular}{|c|c|c|c|c|c|c|}
\hline \multicolumn{7}{|c|}{ MODEL 1: CORPORATE-LEVEL PREDICTORS AS INDEPENDENT VARIABLE } \\
\hline $\begin{array}{l}\text { Total effect of Corporate-level } \\
\text { predictors on R\&D-contrib. role }\end{array}$ & $\begin{array}{l}\text { Direct eff } \\
\text { predictors }\end{array}$ & $\begin{array}{l}\text { fect of Corporate-level } \\
\text { s on R\&D-contrib. role }\end{array}$ & \multicolumn{4}{|c|}{$\begin{array}{l}\text { Indirect effect of Corporate-level } \\
\text { predictors on R\&D-contrib. role }\end{array}$} \\
\hline Coefficient T-value $\begin{array}{c}\text { Bootstrapping } \\
\text { BC 95\% CI }\end{array}$ & Coefficient & T-value $\begin{array}{c}\text { Bootstrapping } \\
\text { BC 95\% CI }\end{array}$ & Mediators & $\begin{array}{c}\text { Point } \\
\text { estimate }\end{array}$ & $\begin{array}{l}\text { Bootstrapping } \\
\text { BC } 95 \% \text { CI }\end{array}$ & Mediation \\
\hline $3.147[0.091,0.402]$ & 0.084 & {$[-0.054,0.223]$} & Total indirect effect & 0.163 & {$[0.076,0.284]$} & \\
\hline & & & External embeddedness & 0.020 & {$[-0.005,0.063]$} & --- \\
\hline & & & External \& Internal embeddedness & 0.009 & {$[-0.003,0.043]$} & --- \\
\hline & & & Internal embeddedness & 0.134 & {$[0.060,0.242]$} & H2: Total \\
\hline \multicolumn{7}{|c|}{ MODEL 2: COUNTRY-LEVEL PREDICTORS AS INDEPENDENT VARIABLE } \\
\hline $\begin{array}{l}\text { Total effect of Country-level } \\
\text { predictors on R\&D-contrib. role }\end{array}$ & $\begin{array}{r}\text { Direct ef } \\
\text { predictors }\end{array}$ & $\begin{array}{l}\text { ffect of Country -level } \\
\text { s on R\&D-contrib. role }\end{array}$ & \multicolumn{4}{|c|}{$\begin{array}{ll}\text { Indirect effect of Country -level } \\
\text { predictors on R\&D-contrib. role }\end{array}$} \\
\hline $\begin{array}{c}\text { Coefficient T-value } \begin{array}{c}\text { Bootstrapping } \\
\text { BC 95\% CI }\end{array} \\
\end{array}$ & Coefficient & T-value $\begin{array}{c}\text { Bootstrapping } \\
\text { BC 95\% CI }\end{array}$ & Mediators & $\begin{array}{c}\text { Point } \\
\text { estimate }\end{array}$ & $\begin{array}{c}\text { Bootstrapping } \\
\text { BC } 95 \% \text { CI }\end{array}$ & Mediation \\
\hline \multirow[t]{4}{*}{$6.461 \quad[0.351,0.662]$} & $0.235^{* *}$ & {$[0.072,0.398]$} & Total indirect effect & 0.272 & {$[0.157,0.413]$} & \\
\hline & & & External embeddedness & 0.130 & {$[0.023,0.263]$} & H1: Partial \\
\hline & & & External \& Internal embeddedness & 0.059 & {$[0.012,0.136]$} & H3: Partial \\
\hline & & & Internal embeddedness & 0.083 & {$[-0.0002,0.181]$} & --- \\
\hline
\end{tabular}

Note: $\mathrm{BC}=$ Bias Corrected; $\mathrm{CI}=$ Confidence Interval; 5,000 bootstrap samples; Confidence level restricted to $99.99 \%, 95 \%$ confidence is provided in output; $* * p<0.01 ; * p<0.05$ (based on a Student $\mathrm{t}(4999)$ distribution, two-tailed test).

'External' represents the path: Country-level predictors $\rightarrow$ External embeddedness $\rightarrow$ Subsidiary competence-creating R $\& D$ role. 'Internal' represents the path: Country-level predictors $\rightarrow$ Internal embeddedness $\rightarrow$ Subsidiary competence-creating R\&D role.

'External\&External' represents the path: Country-level predictors $\rightarrow$ External embeddedness $\rightarrow$ Internal embeddedness $\rightarrow$ Subsidiary competence-creating R\&D role

\section{DISCUSSION AND CONCLUSIONS}

The main contribution of this paper has been to present a multiple mediation model that sheds light on the origin and underlying predictors of the competence-creating R\&D role of an MNC subsidiary. Our findings are consistent with those reported in other studies that identify country- and corporate-level predictors as being the main predictors of strategic $R \& D$ roles, albeit not exactly in the manner that these prior contributions would have led us to expect. By bringing together previous insights from the literature examining subsidiary roles and networks, here we take the analysis one step further and uncover various mediations that determine the strength of internal and external influences. The present study has shown that (1) external embeddedness partially mediates the impact of country-level predictors on subsidiary competence-creating R\&D roles; (2) internal embeddedness fully mediates the impact of corporate-level predictors on subsidiary competence-creating R\&D roles; and, (3) dual embeddedness (where external embeddedness precedes internal embeddedness) also mediates in a sequential manner the relationship between the country-level predictors and the subsidiary's competence-creating $R \& D$ role. These results have several implications.

First, our results suggest that a favourable local environment positively influences the subsidiary's contribution to technology generation within the MNC. This effect exists because local embeddedness establishes the pipeline for sharing, learning and generating knowledge beyond the boundaries of the firm. Thus, a better local environment does not on its own result in the assignment of greater R\&D 
mandates; rather, a subsidiary needs to engage in technological exploration by strengthening linkages with local agents.

However, our results show that a subsidiary's external embeddedness only partially channels the influence of country-level predictors on its competence-creating $R \& D$ role. A possible explanation of this partial mediation is the impact of other equally important factors, including local knowledge spillovers (Audretsch \& Feldman 1996; Almeida \& Kogut, 1999; Alcacer \& Chung, 2007; KaufffeldMonz, 2009) and institutional effects (DiMaggio \& Powell, 1983; Kostova \& Zaheer, 1999)2. Specifically, consideration needs to be given to unintended knowledge spillovers triggered by local labour mobility, free-riders benefiting from alien R\&D investment (Almeida \& Kogut, 1999; Turkan, 2014) or, simply, social capital interaction (i.e. the informal exchange of knowledge among individuals attending social gatherings, such as industry conferences, talks, research seminars, workshops, etc.). Each of these factors is a potential source of accidental and involuntary transfer of tacit knowledge (Audretsch \& Feldman, 1996; Bathelt, Malmberg, \& Maskell, 2004; Turkan, 2014; Şengün, 2015) that can foster R\&D competence-creating roles.

These unintended knowledge spillovers are mainly attributable to the host institutional context (Oerlemans and Meeus, 2005), which shapes the choices, behaviours, interactions and performance of individuals and subsidiaries located in the same region ${ }^{4}$. In fact, institutional factors, including government policies on education and training, the rigidity of labour market regulations (Yi et al, 2015), innovation incentives, public knowledge created by local universities and public research institutes (Schröder, 2014), and knowledge protection practices (Sofka, Shehu, \& de Faria, 2014), also determine the potential of technological spillovers that can boost subsidiary competence-creating roles.

Second, corporate-level predictors appear to be strongly associated with internal embeddedness, which in turn, serves to boost the recognition of competence-creating R\&D mandates among a firm's subsidiaries. However, our results show that no clear relationship exists between corporate-level predictors and a subsidiary's competence-creating $R \& D$ role, except through the channels of internal embeddedness. This finding extends the predictions made in a number of earlier studies conducted from the resource-based view (e.g. Birkinshaw, 1996; Roth \& Morrison, 1992) or from supplementary theories of subsidiary evolution (e.g. Birkinshaw \& Hood, 1998; Cantwell \& Mudambi, 2005; Dörrenbächer \& Gammelgaard, 2006). These earlier studies, undertaken from an atomistic view of

\footnotetext{
${ }^{2} \mathrm{We}$ are grateful to an anonymous referee for suggesting this explanation.

${ }^{3}$ Bathelt et al. (2004) speak of the "local buzz" when referring to the information communicated face-to-face as a result of the co-presence and co-location of people and firms.

${ }^{4}$ In seeking host country legitimacy, institutions establish isomorphic pressures to conform to local shared values, norms, routines and social interactions (DiMaggio \& Powell, 1983; Kostova \& Zaheer, 1999)
} 
MNC subsidiary units, do not consider internal embeddedness as the means by which corporate-level predictors impact a subsidiary's competence-creating R\&D role.

Third, because much of the influence of external embeddedness on a subsidiary's competence-creating $R \& D$ role is conducted through the channels of internal embeddedness, our study confirms the need to consider dual network embeddedness as a key predictor of the role played by subsidiaries as R\&D contributors. In contrast to previous studies that stress the importance of external embeddedness for a subsidiary's role as a competence-creating unit (Andersson, Forsgren, \& Holm, 2001), our study finds that internal embeddedness has a more marked size effect on a subsidiary's acknowledged competences. These findings are more in line with Ambos (2005) who, when examining competence augmenting laboratories, found that internal network partners receive higher scores than external partners. A possible explanation for this might be found in the resource-dependency theory (Mudambi \& Pedersen, 2007). Thus, a subsidiary builds critical linkages with key external actors so as to learn and assimilate knowledge from the host-country environment, and wilfully uses corporate linkages in order to control and transfer value-adding resources, especially knowledge, on which the rest of the MNC can draw (Birkinshaw, Hood, \& Young, 2005) and which they could not otherwise access (Dörrenbächer \& Gammelgaard, 2010). In this situation, a subsidiary's internal embeddedness ensures the dissemination of technological capabilities back to the parent company, and so it is better able to manipulate dependencies and exert influence over the allocation of mandates.

A more exhaustive examination of the relationship between the external and internal embeddedness in our model provides further evidence of interest. Additional analysis in which the line of causality was reversed revealed no significant effect of internal embeddedness on external embeddedness, suggesting that the line of causality runs from external to internal embeddedness. This might be because the former requires some degree of internal embeddedness to impact fully on the level of competences the subsidiary is recognised among the MNC as a whole. This process is of obvious importance, as it should help shed light on how knowledge obtained through external embeddedness can be disseminated to the rest of the firm, and so increase the subsidiary's contribution to the MNC's overall competitive advantage. Our results also reveal a positive sign in this line of causality, which means that a subsidiary's competence-creating R\&D role is affected by the growth of embeddedness in both the local environment and in the corporate network.

This conclusion runs contrary to the predictions of some network-based studies that describe the existence of a trade-off between internal and external network embeddedness (e.g. Andersson et al., 2007). This assumption creates a dilemma similar to the one found in the tension characterising the integration-responsiveness framework (Meyer et al., 2011). Nevertheless, our findings go some way to refuting these previous claims. In line with Narula (2014) who suggests that global and local 
integration are complementary positions, we provide empirical evidence of the subsidiary's capacity to build on both knowledge networks, at least as far as its competence-creating R\&D mandates are concerned. Since the use of each source of knowledge is contingent upon the subsidiary's R\&D role (Athreye, Batsakis \& Singh, 2016), we would expect subsidiaries presenting an inverse relationship between their internal and external embeddedness not to perform a competence-creating R\&D role. Thus, on the basis of our findings, internal and external embeddedness cannot be seen as 'competing' forces; on the contrary, the presence of both forces is an imperative condition that is attributable to the mediating effects they have on each other.

Finally, our results stress the critical role played by internal embeddedness as a channel for transferring knowledge to the rest of the $\mathrm{MNC}$, attracting the attention of headquarters and, thus, having an influence on the allocation of mandates. The potential impact on a subsidiary's competencecreating $R \& D$ role of each of the environmental and relational dimensions analysed herein cannot be fully comprehended until we have fully accounted for their effects as mediated through the channels of internal embeddedness. As such, this study represents an empirical attempt at directly extending and deploying the notion of internal embeddedness as the 'missing link' between the contradictory stances taken to date (Achcaoucaou et al., 2014), i.e. those that report externally embedded subsidiaries as more likely to perform an advanced R\&D role and those that identify external embeddedness as the driver of isolated mandates. As such, this study is one of the first to deal explicitly with their joint effect on subsidiary $R \& D$ roles.

\subsection{Managerial relevance}

Forecasting which subsidiaries will become competence-creating units through an examination not only of the traditional predictors of $\mathrm{R} \& \mathrm{D}$ roles but also of their key mediators (dual network embeddedness) should provide a valuable foundation for firms to design their technological strategies. This has obvious managerial relevance for subsidiary managers and MNC headquarters alike. On the one hand, our model disentangles the way in which different predictors - some of which are initially hidden - help subsidiary managers understand the fate of their R\&D strategic role. In this sense, our analysis alerts subsidiary managers to the fact that, although local embeddedness can be conceived as a facilitator of learning and competence development, and has been traditionally associated with competence-creating R\&D mandates, establishing close-knit, strong relationships with the rest of the MNC is equally important in the development of subsidiary R\&D roles. On the other hand, with regard to the importance of foreign subsidiaries as sources of competences for the MNC as a whole, our results warn headquarters of the contingent importance of not only identifying suitable competitive environments in which to locate, but also determining the real possibilities for establishing longlasting and profitable technological relationships for developing competences in the host countries. 


\subsection{Limitations and future research}

This analysis is not without its limitations (yet, attempts to overcome them should open up exciting avenues of future research). First, for reasons of conceptual and analytical stringency, we have limited our measurement of subsidiary embeddedness to a relatively small number of relationship types that present a high degree of commitment, trust and reciprocity. Clearly, however, widening the type of linkages scrutinised is necessary if we hope to gain further insights. Second, we present evidence in favour of a positive relationship between dual embeddedness and a subsidiary's competence-creating role; however, this positive effect might only occur up to a certain point, beyond which increasing external and/or internal networks may not automatically lead to better subsidiary R\&D competences. In short, much work is needed on determining the optimal levels of external and internal embeddedness. Third, we have only assessed the effect of local business dynamics on the subsidiary's $R \& D$ role and not on other value chain activities, such as marketing or operations, albeit that the impact and type of embeddedness may differ. Future research could usefully validate and extend our findings by including a subsidiary's other international value chain roles. All in all, care should be exercised in defining the boundaries of the value chain activities, the type of networks and the environmental characteristics, bearing in mind that setting such research boundaries is somewhat artificial but, nevertheless, necessary from an analytical point of view (Nell \& Andersson, 2012)

\section{REFERENCES}

Abdi H. (2010). Partial least squares regression and projection on latent structure regression (PLS Regression). WIREs Computational Statistics, 2(1), 97-106

Achcaoucaou, F., Miravitlles, P., \& León-Darder, F. (2014). Knowledge sharing and subsidiary R\&D mandate development: A matter of dual embeddedness. International Business Review, 23(1), 7690 .

Adenfelt, M., \& Lagerström, K. (2006). Knowledge development and sharing in multinational corporations: The case of a centre of excellence and a transnational team. International Business Review, 15(4), 381-400.

Alcacer, J., \& Chung, W. (2007). Location strategies and knowledge spillovers. Management Science, 53(5), 760-776.

Almeida, P., \& Kogut, B. (1999). Localization of knowledge and the mobility of engineers in regional networks. Management Science, 45(7), 905-917.

Al-Tabbaa, O., \& Ankrah, S. (2016). Social capital to facilitate 'engineered'university-industry collaboration for technology transfer: A dynamic perspective. Technological Forecasting and Social Change, 104, 1-15. 
Álvarez, I., Marin, R., \& Fonfria, A. (2009). The role of networking in the competitiveness of firms. Technological Forecasting and Social Change, 76(3), 410-421.

Ambos, B. (2005). Foreign direct investment in industrial research and development: A study of German MNCs. Research Policy, 34(4), 395-410.

Ambos, T. C., Andersson, U., \& Birkinshaw, J. M. (2010). What are the consequences of initiativetaking in multinational subsidiaries? Journal of International Business Studies, 41(7), 1099-1118.

Andersson, U., Dellestrand, H. \& Pedersen, T. (2014). The contribution of local environments to competence creation in multinational enterprises. Long Range Planning, 47 (87-99)

Andersson, U., Forsgren, M., \& Holm, U. (2007). Balancing subsidiary influence in the federative MNC: A business network view. Journal of International Business Studies, 38(5), 802-818.

Andersson, U., Forsgren, M., \& Holm, U. (2001). Subsidiary embeddedness and competence development in MNCs - A multi-level analysis. Organization Studies, 22(6), 1013-1034.

Andersson, U., Forsgren, M., \& Holm, U. (2002). The strategic impact of external networks: Subsidiary performance and competence development in the multinational corporation. Strategic Management Journal, 23(11), 979-996.

Andersson, U., Forsgren, M., \& Pedersen, T. (2001). Subsidiary performance in multinational corporations: The importance of technology embeddedness. International Business Review, $10(1), 3-23$.

Asakawa, K., \& Aoki, T. (2016). Informed headquarters, legitimized subsidiary, and reduced level of subsidiary control in international R\&D management. Research in Global Strategic Management, $17,191-213$.

Asmussen, C. G., Pedersen, T., \& Dhanaraj, C. (2009). Host-country environment and subsidiary competence: Extending the diamond network model. Journal of International Business Studies, $40(1), 42-57$.

Athreye, S., Batsakis, G., \& Singh, S. (2016). Local, global, and internal knowledge sourcing: The trilemma of foreign-based R\&D subsidiaries. Journal of Business Research, 69(12), 5694-5702.

Audretsch, D. B., \& Feldman, M. P. (1996). Innovative clusters and the industry life cycle. Review of Industrial Organization, 11(2), 253-273.

Baron, R. M., \& Kenny, D. A. (1986). The moderator mediator variable distinction in social psychological-research - conceptual, strategic, and statistical considerations. Journal of Personality and Social Psychology, 51(6), 1173-1182.

Barringer, B. R., \& Bluedorn, A. C. (1999). The relationship between corporate entrepreneurship and strategic management. Strategic Management Journal, 20(5), 421-444.

Bathelt, H., Malmberg, A. \& Maskell, P. (2004). Clusters and knowledge: local buzz, global pipelines and the process of knowledge creation. Progress in Geography, 28, 31-56.

Beise, M. (2004). Lead markets: Country-specific drivers of the global diffusion of innovations. Research Policy, 33(6-7), 997-1018. 
Benito, G. R. G., Grøgaard, J. B., \& Narula, R. (2003). Environmental influences on MNE subsidiary roles: Economic integration and the nordic countries. Journal of International Business Studies, 34(5), 443-443.

Belderbos, R. (2003). Entry mode, organizational learning, and R\&D in foreign affiliates: Evidence from japanese firms. Strategic Management Journal, 24(3), 235-259.

Berghman, L., Matthyssens, P., Streukens, S., \& Vandenbempt, K. (2013). Deliberate learning mechanisms for stimulating strategic innovation capacity. Long Range Planning, 46(1-2), 39-71.

Bresciani, S., \& Ferraris, A. (2016). Innovation-receiving subsidiaries and dual embeddedness: impact on business performance. Baltic Journal of Management, 11(1), 108-130.

Birkinshaw, J. M. (1996). How multinational subsidiary mandates are gained and lost. Journal of International Business Studies, 27(3), 467-495.

Birkinshaw, J. M. (1997). Entrepreneurship in multinational corporations: The characteristics of subsidiary initiatives. Strategic Management Journal, 18(3), 207-229.

Birkinshaw, J. M., \& Hood, N. (1998). Multinational subsidiary evolution: Capability and charter change in foreign-owned subsidiary companies. The Academy of Management Review, 23(4), 773-795.

Birkinshaw, J. M., Hood, N., \& Jonsson, S. (1998). Building firm-specific advantages in multinational corporations: The role of subsidiary initiative. Strategic Management Journal, 19(3), 221-241.

Birkinshaw, J. M., Hood, N., \& Young, S. (2005). Subsidiary entrepreneurship, internal and external competitive forces, and subsidiary performance. International Business Review, 14(2), 227-248.

Birkinshaw, J. M., \& Ridderstråle, J. (1999). Fighting the corporate immune system: A process study of subsidiary initiatives in multinational corporations. International Business Review, 8(2), 14980 .

Björkman, I., Barner-Rasmussen, W., \& Li, L. (2004). Managing knowledge transfer in MNCs: The impact of headquarters control mechanisms. Journal of International Business Studies, 35(5), 443-455.

Bouquet, C., \& Birkinshaw, J. M. (2008). Weight versus voice: How foreign subsidiaries gain attention from corporate headquarters. Academy of Management Journal, 51(3), 577-601.

Cantwell, J. (2009). Location and the multinational enterprise. Journal of International Business Studies, 40(1), 35-41.

Cantwell, J., \& Mudambi, R. (2005). MNE competence-creating subsidiary mandates. Strategic Management Journal, 26(12), 1109-1128.

Carmines, E. G., \& Zeller, R. A. (1979). Reliability and validity assessment. Beverly Hills California: Sage.

Cavanagh, A., \& Freeman, S. (2012). The development of subsidiary roles in the motor vehicle manufacturing industry. International Business Review, 21(4), 602-617.

Cenfetelli, R. T., \& Bassellier, G. (2009). Interpretation of formative measurement in information systems research. Mis Quarterly, 33(4), 689-707. 
Chin, W. W. (1998). The partial least squares approach to structural equation modelling. In A. Marcoulides (Ed.), Modern methods for business research (pp. 295-336). Mahwah NJ: Lawrence Erlbaum Associates Publisher.

Chin, W. W. (2010). How to write up and report PLS analyses. In V. Esposito Vinzi, W. W. Chin, J. Henseler \& H. Wang (Eds.), Handbook of partial least squares: Concepts, methods and applications (pp. 655-590). Germany: Springer Handbooks of Computational Statistics.

Ciabuschi, F., Dellestrand, H., \& Martín Martín, O. (2011). Internal embeddedness, headquarters involvement, and innovation importance in multinational enterprises. Journal of Management Studies, 48(7), 1612-1639.

Ciabuschi, F., Holm, U., \& Martín Martín, O. (2014). Dual embeddedness, influence and performance of innovating subsidiaries in the multinational corporation. International Business Review, 23(5), 897-909.

Cohen, J. (1998). Statistical power analysis for the behavioral sciences. Hilsdale, NJ: Lawrence Erlbaum Associates, 2 edition.

Collinson, S. C., \& Wang, R. (2012). The evolution of innovation capability in multinational enterprise subsidiaries: Dual network embeddedness and the divergence of subsidiary specialisation in Taiwan. Research Policy, 41(9), 1501-1518.

Conroy, K. M., \& Collings, D. G. (2016). The legitimacy of subsidiary issue selling: Balancing positive \& negative attention from corporate headquarters. Journal of World Business, 51(4), 612-627.

Covin, J. G., \& Slevin, D. P. (1989). Strategic management of small firms in hostile and benign environments. Strategic Management Journal, 10(1), 75-87.

Dacin, M. T., Ventresca, M. J., \& Beal, B. D. (1999). The embeddedness of organizations: Dialogue \& directions. Journal of Management, 25(3), 317-356.

Diamantopoulos, A., \& Winklhofer, H. M. (2001). Index construction with formative indicators: An alternative to scale development. Journal of Marketing Research, 38(2), 269-277.

DiMaggio, P. J., \& Walter, W. P. (1983). The iron cage revisited: institutional isomorphism and collective rationality in organizational fields. American Sociological Review, 48(2), 147-160.

Dörrenbächer, C., \& Gammelgaard, J. (2006). Subsidiary role development: The effect of micropolitical headquarters-subsidiary negotiations on the product, market and value-added scope of foreign-owned subsidiaries. Journal of International Management, 12(3), 266-283.

Dörrenbächer, C., \& Gammelgaard, J. (2010). Multinational corporations, inter-organizational networks and subsidiary charter removals. Journal of World Business, 45(3), 206-216.

Dutton, J. E., Ashford, S. J., O'Neill, R. M., \& Lawrence, K. A. (2001). Moves that matter: Issue selling and organizational change. Academy of Management Journal, 44(4), 716-736.

Dyer, J. H., \& Singh, H. (1998). The relational view: Cooperative strategy and sources of interorganizational competitive advantage. Academy of Management Review, 23(4), 660-679.

Edler, J. (2004). International research strategies of multinational corporations: A German perspective. Technological Forecasting and Social Change, 71(6), 599-621. 
Egbetokun, A. A. (2015). Interactive learning and firm-level capabilities in latecomer settings: The Nigerian manufacturing industry. Technological Forecasting and Social Change, 99, 599-621.

Falk, R. F., \& Miller, N. B. (1992). A primer for soft modelling. Ohio: University of Akron Press.

Faul, F., Erdfelder, E., Lang, A. G., \& Buchner, A. (2007). G*power 3: A flexible statistical power analyisis program for the social, behavioral and biomedial sciences. Behavior Research Methods, 39(2), 175-191.

Figueiredo, P. N. (2011). The role of dual embeddedness in the innovative performance of MNE subsidiaries: Evidence from Brazil. Journal of Management Studies, 48(2), 417-440.

Fornell, C., \& Larcker, D. F. (1981). Evaluating structural equation models with unobservable variables and measurement error. Journal of Marketing Research, 18(1), 39-50.

Forsgren, M., Holm, U., \& Johanson, J. (2005). Managing the embedded multinational: A business network view. Cheltenham: Edward Elgar Publishing.

Foss, N. J., \& Pedersen, T. (2002). Transferring knowledge in MNCs: The role of sources of subsidiary knowledge and organizational context. Journal of International Management, 8(1), 49-67.

Foss, N. J., \& Pedersen, T. (2004). Organizing knowledge processes in the multinational corporation: An introduction. Journal of International Business Studies, 35(5), 340-349.

Frost, T. S. (2001). The geographic sources of foreign subsidiaries' innovations. Strategic Management Journal, 22(2), 101-123.

Frost, T. S., Birkinshaw, J. M., \& Ensign, P. C. (2002). Centers of excellence in multinational corporations. Strategic Management Journal, 23(11), 997-1018.

Garcia-Pont, C., Canales, J. I., \& Noboa, F. (2009). Subsidiary strategy: The embeddedness component. Journal of Management Studies, 46(2), 182-214.

Geisser, S. (1974). A predictive approach to the random effect model. Biometrika, 61(1), 101-107.

Ghoshal, S., \& Bartlett, C. A. (1990). The multinational corporation as an interorganizational network. The Academy of Management Review, 15(4), 603-625.

Ghoshal, S., \& Bartlett, C. A. (1994). Linking organizational context and managerial action - the dimensions of quality of management. Strategic Management Journal, 15, 91-112.

Ghoshal, S., \& Nohria, N. (1989). Internal differentiation of the determinants of global integration. Strategic Management Journal, 10(4), 323-337.

Giroud, A., \& Scott-Kennel, J. (2009). MNE linkages in international business: A framework for analysis. International Business Review, 18(6), 555-566.

Gulati, R. (1999). Network location and learning: The influence of network resources and firm capabilities on alliance formation. Strategic Management Journal, 20(5), 397-420.

Gupta, A. K., \& Govindarajan, V. (2000). Knowledge flows within multinational corporations. Strategic Management Journal, 21(4), 473-496. 
Hair, J. F., Sarstedt, M., Pieper, T. M., \& Ringle, C. M. (2012). The use of partial least squares structural equation modeling in strategic management research: A review of past practices and recommendations for future applications. Long Range Planning, 45(5-6), 320-340.

Håkansson, H., \& Snehota, I. (1995). Developing relationships in business networks (1st ed.). London: Routledge.

Harzing, A., \& Noorderhaven, N. (2006). Knowledge flows in MNCs: An empirical test and extension of Gupta and Govindarajan's typology of subsidiary roles. International Business Review, 15(3), 195-214.

Hayes, A. F., Preacher, K. J., \& Myers, T. A. (2011). Mediation and the estimation of indirect effects in political communication research. In E. P. Bucy, \& R. L. Holbert (Eds.), Sourcebook for political communication research: Methods, measures and analytical techniques (pp. 434-465). New York: Routledge.

Helble, Y., \& Chong, L. C. (2004). The importance of internal and external R\&D network linkages for R\&D organisations: Evidence from singapore. $R \&$ D Management, 34(5), 605-612.

Holm, U., Holmström, C., \& Sharma, D. (2005). Competence development through business relationships or competitive environment? - subsidiary impact on MNC competitive advantage. MIR: Management International Review, 45(2), 197-218.

Holm, U., Malmberg, A., \& Sölvell, Ö. (2003). Subsidiary impact on host-country economies - the case of foreign-owned subsidiaries attracting investment into sweden. Journal of Economic Geography, 3(4), 389-408.

Iammarino, S., Padilla-Perez, R., \& Von Tunzelmann, N. (2008). Technological capabilities and global-local interactions: The electronics industry in two mexican regions. World Development, 36(10), 1980-2003.

Jaffe, A.B., Trajtenberg, M., Henderson. R. (1993).Geographic localization of knowledge spillovers as evidenced by patent citations. Quarterly Journal of Economics 108 ,577-598.

Jarillo, J. C., \& Martínez, J. I. (1990). Different roles for subsidiaries: The case of multinational corporations in spain. Strategic Management Journal, 11(7), 501-512.

Jarvis, C. B., MacKenzie, S. B., \& Podsakoff, P. M. (2003). A critical review of construct indicators and measurement model misspecification in marketing and consumer research. Journal of Consumer Research, 30(2), 199-218.

Judd, C. M., \& Kenny, D. A. (1981). Process analysis - estimating mediation in treatment evaluations. Evaluation Review, 5(5), 602-619.

Kauffeld-Monz, M. (2009). Knowledge spillovers within regional networks of innovation and the contribution made by public research. IUP Journal of Knowledge Management, 7(3/4), 41-63.

Kleinbaum, D. G., Kupper, L. L., \& Muller, K. E. (1988). Applied regression analysis and other multivariable methods (2nd ed.). Boston Mass.: Pws-Kent.

Kostova, T., \& Zaheer, S. (1999). Organizational legitimacy under conditions of complexity: The case of the multinational enterprise. Academy of Management Review, 24(1), 64-81. 
Kuratko, D. F., Montagno, R. V., \& Hornsby, J. S. (1990). Developing an intrapreneurial assessment instrument for an effective corporate entrepreneurial environment. Strategic Management Journal, 11(Special issue), 49-58.

Liang, H., Saraf, N., Hu, Q., \& Xue, Y. (2007). Assimilation of enterprise systems: The effect of institutional pressures and the mediating role of top management. Mis Quarterly, 31(1), 59-87.

Ling, Y., Floyd, S. W., \& Baldridge, D. C. (2005). Toward a model of issue-selling by subsidiary managers in multinational organizations. Journal of International Business Studies, 36(6), 637654.

MacKinnon, D. P., Lockwood, C. M., \& Williams, J. (2004). Confidence limits for the indirect effect: Distribution of the product and resampling methods. Multivariate Behavioral Research, 39(1), 99-128.

Manolopoulos, D., Dimitratos, P., Young, S., \& Lioukas, S. (2009). Technology sourcing and performance of foreign subsidiaries in greece: The impact of MNE and local environmental contexts. Management International Review, 49(1), 43-60.

Meyer, K. E., Mudambi, R., \& Narula, R. (2011). Multinational enterprises and local contexts: The opportunities and challenges of multiple embeddedness. Journal of Management Studies, 48(2), $235-252$.

Miller, D., \& Friesen, P. H. (1982). Innovation in conservative and entrepreneurial firms: Two models of strategic momentum. Strategic Management Journal, 3(1), 1-25.

Minbaeva, D. B., Pedersen, T., Björkman, I., Fey, C. F., \& Park, H. J. (2003). MNC knowledge transfer, subsidiary absorptive capacity, and HRM. Journal of International Business Studies, 34(6), 586-599.

Monteiro, L. F., Arvidsson, N., \& Birkinshaw, J. M. (2008). Knowledge flows within multinational corporations: Explaining subsidiary isolation and its performance implications. Organization Science, 19(1), 90-107.

Moore, K. J. (2001). A strategy for subsidiaries: Centres of excellences to build subsidiary specific advantages. Management International Review, 41(3), 275-290.

Mudambi, R., \& Navarra, P. (2004). Is knowledge power? knowledge flows, subsidiary power and rent-seeking within MNCs. Journal of International Business Studies, 35(5), 385-406.

Mudambi, R., \& Pedersen, T. (2007). Agency theory and resource dependency theory: Complementary explanations for subsidiary power in multinational corporations. Unpublished manuscript.

Narula, R. (2014). Exploring the Paradox of Competence-creating subsidiaries: Balancing Bandwidh and Dispersion in MNEs, Long Range Planning, 47 (4-15)

Nell, P. C., \& Andersson, U. (2012). The complexity of the business network context and its effect on subsidiary relational (over-) embeddedness. International Business Review, 21(6), 1087-1098.

Nunnally, J. C. (1978). Psychometric theory (2nd ed.). New York: McGraw-Hill.

Oehmichena, J., \& Puck, J. (2016). Embeddedness, ownership mode and dynamics, and the 'performance of MNE subsidiaries. Journal of International Management, 22(1), 17-28. 
Oerlemans, L. A. G., \& Meeus, M. T. H. (2005). Do organizational and spatial proximity impact on firm performance?. Regional Studies, 39(1), 89-104.

Pearce, R. D. (1999). Decentralised R\&D and strategic competitiveness: Globalised approaches to generation and use of technology in multinational enterprises (MNEs). Research Policy, 28(2-3), $157-178$.

Podsakoff, P. M., MacKenzie, S. B., Lee, J. Y., \& Podsakoff, N. P. (2003). Common method biases in behavioral research: A critical review of the literature and recommended remedies. Journal of Applied Psychology, 88(5), 879-903.

Porter, M. E. (1980). Competitive strategy. Nueva York: Free Press.

Porter, M. E. (1990). The competitive advantage of nations. London: Macmillan.

Preacher, K. J., \& Hayes, A. F. (2004). SPSS and SAS procedures for estimating indirect effects in simple mediation models. Behavior Research Methods Instruments \& Computers, 36(4), 717731.

Preacher, K. J., \& Hayes, A. F. (2008). Asymptotic and resampling strategies for assessing and comparing indirect effects in multiple mediator models. Behavior Research Methods, 40(3), 879891.

Reilly, M., \& Scott, P. S. (2014). Subsidiary driven innovation within shifting MNC structures: Identifying new challenges and research directions. Technovation, 34(3), 190-202.

Reinartz, W., Haenlein, M., \& Henseler, J. (2009). An empirical comparison of the efficacy of covariance-based and variance-based SEM. International Journal of Research in Marketing, $26(4), 332-344$.

Ringle, C. M., Götz, O., Wetzels, M., \& Wilson, B. (2009). On the use of formative measurement specifications in structural equation modeling: A monte carlo simulation study to compare covariance-based and partial least squares model estimation methodologies. Research Memoranda 014, Maastricht: METEOR, Maastricht Research School of Economics of Technology and Organization.

Ringle, C. M., Sarstedt, M., \& Straub, D. W. (2012). A critical look at the use of PLS-SEM in MIS quarterly. Mis Quarterly, 36(1), III-XIV.

Ringle, C. M., Wende, S., \& Will, A. (2005). SmartPLS 2.0 (beta). Hamburg: www.smartpls.de.

Roth, K., \& Morrison, A. J. (1992). Implementing global strategy: Characteristics of global subsidiary mandates. Journal of International Business Studies, 23(4), 715-735.

Rugman, A. M., \& Verbeke, A. (2004). A perspective on regional and global strategies of multinational enterprises. Journal of International Business Studies, 35(1), 3-18.

Santangelo, G. D. (2009). MNCs and linkages creation: Evidence from a peripheral area. Journal of World Business, 44(2), 192-205.

Santangelo, G. D. (2012). The tension of information sharing: Effects on subsidiary embeddedness. International Business Review, 21(2), 180-195. 
Schneckenberg, D., Truong, Y., \& Mazloomi, H. (2015). Microfoundations of innovative capabilities: The leverage of collaborative technologies on organizational learning and knowledge management in a multinational corporation. Technological Forecasting and Social Change, 100, 356-368.

Schhröder, Ch. (2014). Dynamics in ICT cooperation networks in selected German ICT clusters. International Economic and Economics policy 11, 197-230

Scott, P., Gibbons, P., \& Coughlan, J. (2010). Developing subsidiary contribution to the MNCsubsidiary entrepreneurship and strategy creativity. Journal of International Management, 16(4), 328-339.

Şengün, A.E. (2015). Does informal knowledge sharing breed innovation in industrial clusters?. Boğaziçi Journal Review of Social, Economic and Administrative Studies, 29, (1) 53-79.

Shaver, J. M., \& Flyer, F. (2000). Agglomeration economies, firm heterogeneity, and foreign direct investment in the United States. Strategic Management Journal, 21(12), 1175-1193.

Sobel, M. E. (1982). Asymptotic confidence intervals for indirect effects in structural equation models. Sociological Methodology, 13, 290-312.

Sofka, W., Shehu, E., \& de Faria, P. (2014). Multinational subsidiary knowledge protection-Do mandates and clusters matter? Research Policy, 43(8), 1320-1333.

Stone, M. (1974). Cross-validatory choice and assessment of statistical predictions. Journal of the Royal Statistical Society Series B-Statistical Methodology, 36(2), 111-147.

Sun, H. (2010). Sellers' trust and continued use of online marketplaces. Journal of the Association for Information Systems, 11(4), 182-211.

Taggart, J. H. (1996). Multinational manufacturing subsidiaries in Scotland: Strategic role and economic impact. International Business Review, 5(5), 447-468.

Tallman, S., \& Chacar, A. S. (2011). Knowledge accumulation and dissemination in MNEs: A practice-based framework. Journal of Management Studies, 48(2), 278-304.

Turckan, B. (2014). Knowledge externalities and knowledge spillovers in social networks: the case of Izmir metalwork industrial district. European Planning Studies, 22 (7), 1425-1443.

Venaik, S., Midgley, D. F., \& Devinney, T. M. (2005). Dual paths to performance: The impact of global pressures on MNC subsidiary conduct and performance. Journal of International Business Studies, 36(6), 655-675.

Verbeke, A., \& Yuan, W. (2013). The drivers of multinational enterprise subsidiary entrepreneurship in china: A new resource-based view perspective. Journal of Management Studies, 50(2), 236258.

Wang, J., Liu, X., \& Li, X. (2009). A dual-role typology of multinational subsidiaries. International Business Review, 18(6), 578-591.

Wang, Y., \& Suh, C. S. (2009). Towards a re-conceptualization of firm internationalization: Heterogeneous process, subsidiary roles and knowledge flow. Journal of International Management, 15(4), 447-459. 
Wetzels, M., Odekerken-Schroder, G., \& van Oppen, C. (2009). Using pls path modeling for assessing hierarchical construct models: Guidelines and empirical illustration. Mis Quarterly, 33(1), 177195.

Wilden, R., Gudergan, S. P., Nielsen, B. B., \& Lings, I. (2013). Dynamic capabilities and performance: Strategy, structure and environment. Long Range Planning, 46(1-2), 72-96.

Wold, H. (1982). Soft modeling: The basic design and some extensions. In K. G. Jöreskog, \& H. Wold (Eds.), Systems under indirect observation, vol. 2 (pp. 589-591). Amsterdam: North Holland.

Yamin, M., \& Andersson, U. (2011). Subsidiary importance in the MNC: What role does internal embeddedness play? International Business Review, 20(2), 151-162.

Yi, J., Chen, Y., Wang, Ch. \& Kafouros, M.(2015). Spillover effects of foreign direct investment: how do Region-Specific Institutions Matter? Management International Review, 55, 539-561.

Young, S., \& Tavares, A. T. (2004). Centralization and autonomy: Back to the future. International Business Review, 13(2), 215-237.

Zander, I. (1999). How do you mean 'global'? An empirical investigation of innovation networks in the multinational corporation. Research Policy, 28(2-3), 195-213.

Dimitratos, P., Liouka, I., \& Young, S. (2014). A Missing Operationalization: Entrepreneurial Competencies in Multinational Enterprise Subsidiaries. Long Range Planning, 47(1-2), 64-75. 